\title{
Augmentation of the anticancer effects of proteasome inhibitors by combination with sodium butyrate in human colorectal cancer cells
}

\author{
M.S.I. ABAZA \\ Molecular Biology Program, Department of Biological Sciences, Faculty of Science, Kuwait University, State of Kuwait
}

Received March 12, 2010; Accepted June 7, 2010

DOI: 10.3892/etm_00000106

\begin{abstract}
The ubiquitin-proteasome pathway plays a critical role in the degradation of cellular proteins and cell cycle control. As such, dysregulating the degradation of such proteins should have profound effects on tumor growth and should cause cells to undergo apoptosis. Proteasome inhibitors display marked anticancer tendencies in hematopoietic cells; however, this activity is much less potent against solid tumor malignant cells. In addition, it can mediate toxicities such as peripheral neuropathy and can induce primary/secondary resistances. These observations prompted us to investigate whether sodium butyrate $(\mathrm{NaB})$, a natural product for inducing tumor cell apoptosis that exhibits a low degree of clinical toxicity, can enhance the anticancer effects of the proteasome inhibitors MG115, MG132, PSI-1, PSI-2 and epoxomicin in human colorectal cancer. Combinations of the proteasome inhibitors and $\mathrm{NaB}$ markedly inhibited the proliferation of human colorectal cancer cells in a dose- and time-dependent manner, particularly compared to single treatment with $\mathrm{NaB}$ and the proteasome inhibitors. A combination of the proteasome inhibitors and $\mathrm{NaB}$ produced additive and synergistic growth inhibitory effects. The human colorectal cancer cells treated with $\mathrm{NaB}$, proteasome inhibitors, and their combinations exhibited growth arrest at the $G_{1}, G_{2}-M / S$, and $G_{1}$ or $S /$ $\mathrm{G}_{2}-\mathrm{M}$ phases of the cell cycle, respectively. $\mathrm{NaB}$ stimulated the conversion of procaspase- 3 into caspase- 3 and induced the cleavage of poly(ADP-ribose) polymerase and lamin-B, which are two hallmarks of apoptosis. $\mathrm{NaB}$, the proteasome inhibitor epoxomicin, and their combination stimulated the release of cytochrome- $c$ from mitochondria, which was most likely responsible for the activation of caspase-3. Combined
\end{abstract}

Correspondence to: Dr Mohamed-Salah I. Abaza, Molecular Biology Program, Department of Biological Sciences, Faculty of Science, Kuwait University, P.O. Box 5969, 13060 Safat, State of Kuwait

E-mail: abaza@kuc01.kuniv.edu.kw

Key words: proteasome inhibitors, sodium butyrate, colorectal cancer, growth inhibition, synergy, apoptosis induction, cell cycle modulation treatment with $\mathrm{NaB}$ and the proteasome inhibitors caused marked induction of apoptosis compared to single treatments of the proteasome inhibitors and $\mathrm{NaB}$; the apoptotic signals were abolished by the inhibitors of caspase- 3 activity. The proteasome inhibitors and their combinations with $\mathrm{NaB}$ counteracted the suppressive effect that was induced by $\mathrm{NaB}$ on the levels of $\mathrm{p} 53$. $\mathrm{NaB}$, the proteasome inhibitors and their combinations decreased the levels of $\mathrm{BcL} 2$, but increased the levels of Bax, p21 $1^{\text {Wafl }}$ and p27 ${ }^{\mathrm{Kip} 1}$. Taken together, these results indicate a synergistic interaction between proteasome inhibitors and sodium butyrate that could present a new approach for the treatment of colorectal cancer.

\section{Introduction}

The ubiquitin-proteasome system (UPS) mediates the degradation of polyubiquitinated proteins and represents the main protein degradation pathway in eukaryotic cells (1). It is estimated that over $80 \%$ of intracellular proteins are degraded by the proteasome. By catalyzing limited or complete degradation of proteins, the UPS plays a role in many basic cellular processes, such as differentiation (2) proliferation (3), apoptosis (3), gene transcription (4), signal transduction (5), metabolic regulation (6), and immune surveillance (7), among others (8). Thus, the UPS is essential for the development and maintenance of all eukaryotic cells (9), implying that the UPS is also inevitably involved in pathophysiological processes that result in the development of many diseases, including autoimmune, neurodegenerative and rheumatoid diseases, viral infections, cachexia and cancer.

Based on the unique potential for cellular regulation via the UPS, several proteasome inhibitors have been developed. The possibility that proteasome inhibitors could be drug candidates was considered after studies demonstrated that they induced apoptosis in leukemia cell lines (10), including chemotherapyand radiation-resistant chronic lymphocytic leukemia cells (11). This possibility was bolstered by findings that proteasome inhibitors preferentially induced apoptosis in transformed cells (11). Later, studies documented the efficacy of proteasome inhibition against preclinical models both as a single approach and in chemosensitization and overcoming resistance (12).

Proteasome inhibitors are targeted since they are extremely potent and selective. Due to their effect on the proteolysis of 
a wide array of cellular proteins, however, they share characteristics with general cytotoxic agents, such as vinflunine, straplatin, aurora kinase inhibitors and epothilones (13). In light of this, proteasome inhibitors have several important mechanisms of action, beyond their effects on $\mathrm{NF \kappa B}$, that have been preclinically validated in cell line models (14). By interfering with the timely degradation of cyclins and other cell cycle regulatory proteins, proteasome inhibitors induce cell cycle arrest. Through their ability to stabilize pro-apoptotic proteins such as p53 and Bax while reducing levels of certain anti-apoptotic proteins such as BcL2, they also induce a pro-apoptotic state. Other mechanisms include the induction of aggresome formation, endoplasmic reticulum stress and unfolded protein response (15).

Although proteasome inhibitors display marked anticancer effects in hematopoietic cells, they exhibit much less anticancer activity against solid tumor malignant cells, mediate toxicities such as peripheral neuropathy, and induce primary and secondary resistances. These observations prompted us to investigate whether sodium butyrate $(\mathrm{NaB})$, a natural product of apoptosis that exhibits a low degree of clinical toxicity, can enhance the anticancer effect of the proteasome inhibitors MG115, MG132, PSI-1, PSI-2 and epoxomicin in human colorectal carcinoma.

Butyrate is a short 4-carbon fatty acid, one of three found in the mammalian colonic lumen (16). It is produced by anaerobic bacteria that ferment undigested dietary carbohydrates (mainly fiber) and protein (17). Butyrate has been considered to be a biological response modifier; that is, a reagent that has generally reversible effects on gene activation and growth control (18). Butyrate inhibits DNA synthesis, arrests actively proliferating cells of many tissue types (19), and induces differentiation in certain cell types. These observations have led investigators to propose that butyrate, a byproduct of microbial fermentation of fiber in the colonic milieu, may have an antiproliferative, and potentially an antineoplastic, effect on mucosal epithelial cells (20). Due to its growth inhibitory effects and low toxicity, butyrate was tested in this study in order to potentiate the anticancer effects of a group of proteasome inhibitors (MG115, MG132, PSI-1, PSI-2 and epoxomicin) towards solid tumor colorectal cancer cells. The effects of single and combined treatment with proteasome inhibitors and $\mathrm{NaB}$ on cell cycle progression, stabilization of p53 protein, induction of $\mathrm{p} 53$-inducible gene products, and the triggering of the apoptotic pathway were also investigated.

\section{Materials and methods}

Cell culture and reagents. Human colorectal cancer cell lines (SW48, SW1116, and SW837) were obtained from the American Type Culture Collection (ATCC, Rockville, MD, USA). The cells were cultured in Leibovitz's L-15 medium supplemented with $10 \%$ inactivated fetal bovine serum and $2 \mathrm{mM}$ glutamine. The L-15 medium formulation was devised for use in a free gas exchange with atmospheric air. $\mathrm{CO}_{2}$ is detrimental to cells when using this medium for cultivation. Goat polyclonal anti-human Bax, CPP32 and lamin B, rabbit polyclonal anti-human PARP and mouse monoclonal anti-human BcL2, cytochrome-c, Bax, p53, p21 ${ }^{\text {Waf1}}$, p27 ${ }^{\text {Kip1 }}$ and $\beta$-actin were purchased from Santa Cruz Biotechnology
Inc. (Santa Cruz, CA, USA). MG115, MG132, PSI-1, PSI-2 and epoxomicin were purchased from Biomol Research Laboratories, Inc. (Plymouth, Meeting, PA, USA). Sodium butyrate and Ac-DEVD were obtained from the Sigma Chemical Co. (St. Louis, MO), and z-VAD-fmk was obtained from Bachem AG (Bubendorf, Switzerland). Stock solutions of z-VAD-fmk (100 mM) and Ac-DEVD (200 mM) were prepared in methanol and DMSO, respectively.

Time- and dose-dependent antiproliferative effects of proteasome inhibitors and $\mathrm{NaB}$ on human colorectal cancer cells. Human colorectal cancer cell lines (SW48, SW1116 and SW837) were plated $\left(27 \times 10^{3}\right.$ cells/well) into 96-well plates and treated with $\mathrm{NaB}(0.195-12.5 \mathrm{mM}), \mathrm{MG} 115$ (0.06-4.0 $\mu \mathrm{M})$, MG132 (0.06-4.0 $\mu \mathrm{M})$, PSI-1 (0.03-4.0 $\mu \mathrm{M})$, PSI-2 (0.03-4.0 $\mu \mathrm{M})$ and epoxomicin (7.8-62.5 $\mathrm{nM}$ ) beginning $24 \mathrm{~h}$ after seeding the cells in culture. The final DMSO concentration in proteasome-treated cells was $0.1 \%$; all control cultures were treated with the same $0.1 \%$ DMSO to control for any effect that DMSO may exert on the cells. Cell proliferation was determined at various time periods using an MTT assay.

Augmentation of the anticancer effects of proteasome inhibitors by their combination with $\mathrm{NaB}$. The potential of butyrate to sensitize human colorectal cancer cells to proteasome inhibitors was determined as previously described (21). Colorectal cancer cell lines (SW48, SW1116 and SW837) were plated $\left(27 \times 10^{3}\right.$ cells/well) into 96 -well plates and incubated at $37^{\circ} \mathrm{C}$ in a non- $\mathrm{CO}_{2}$ incubator. The cells were then treated with $\mathrm{NaB}$, proteasome inhibitors (MG115, MG132, PSI-1, PSI-2 and epoxomicin), or combinations of $\mathrm{NaB}$ and each of the tested proteasome inhibitors. The experiment began $18 \mathrm{~h}$ after seeding the cells in culture; control cells were left untreated. Cell proliferation was determined at various time periods (1, 3, and 5 days) by an MTT assay. The concentrations of $\mathrm{NaB}$ and the proteasome inhibitors used for single treatment experiment were $\mathrm{NaB}$ (1.5-12.5 mM), MG115 (0.25-2.0 $\mu \mathrm{M})$, MG132 (0.25-2.0 $\mu \mathrm{M})$, PSI-1 (0.013-0.1 $\mu \mathrm{M})$, PSI-2 (0.375-3.0 $\mu \mathrm{M})$ and epoxomicin (3.0-12.0 $\mathrm{nM})$. Meanwhile, the concentrations of the combined treatments were $\mathrm{NaB}$ and MG115 $(1.56 \mathrm{mM} / 0.25 \mu \mathrm{M}, 3.125 \mathrm{mM} / 0.5 \mu \mathrm{M}$, $6.25 \mathrm{mM} / 1.0 \mu \mathrm{M}, 12.5 \mathrm{mM} / 2.0 \mu \mathrm{M}), \mathrm{NaB}$ and $\mathrm{MG} 132$ (1.56 mM/0.25 $\mu \mathrm{M}, 3.125 \mathrm{mM} / 0.5 \mu \mathrm{M}, 6.25 \mathrm{mM} / 1.0 \mu \mathrm{M}$ and $12.5 \mathrm{mM} / 2.0 \mu \mathrm{M}), \mathrm{NaB}$ and PSI-1 (1.56 mM/0.013 $\mu \mathrm{M}$, $3.125 \mathrm{mM} / 0.025 \mu \mathrm{M}, 6.25 \mathrm{mM} / 0.05 \mu \mathrm{M}, 12.5 \mathrm{mM} / 0.1 \mu \mathrm{M})$, $\mathrm{NaB}$ and PSI-2 (1.56 mM/0.375 $\mu \mathrm{M}, 3.125 \mathrm{mM} / 0.75 \mu \mathrm{M}$, $6.25 \mathrm{mM} / 1.5 \mu \mathrm{M}, 12.5 \mathrm{mM} / 3.0 \mu \mathrm{M})$, and $\mathrm{NaB}$ and epoxomicin $(1.56 \mathrm{mM} / 3.0 \mathrm{nM}, 3.125 \mathrm{mM} / 6 \mathrm{nM}, 6.25 \mathrm{mM} / 9.0 \mathrm{nM}$ and $12.5 \mathrm{mM} / 12.0 \mathrm{nM})$.

Assessment of the type of interaction between NaB and proteasome inhibitors in human colorectal cancer cells. Human colorectal cancer cell lines (SW48, SW1116 and SW837) were treated with $\mathrm{NaB}(1.56,3.125,6.25,12.5 \mathrm{mM}), \mathrm{MG} 115$ (0.25, 0.5, 1.0, 2.0 $\mu \mathrm{M})$, MG132 $(0.25,0.5,1.0,2.0 \mu \mathrm{M})$, PSI-1 (0.013, 0.025, 0.05, 0.1 $\mu \mathrm{M})$, PSI-2 (0.375, 0.75, 1.5, $3.0 \mu \mathrm{M})$, epoxomicin $(3.0,6.0,9.0,12.0 \mathrm{nM})$, and the same combinations of $\mathrm{NaB}$ and proteasome inhibitors that were previously mentioned. The interactions of the tested combinations on 
human colorectal cancer cell growth were determined as previously described $(22,23)$, using the following formulas: $\mathrm{SF}_{\mathrm{A}+\mathrm{B}}$ $>\left(\mathrm{SF}_{\mathrm{A}}\right) \times\left(\mathrm{SF}_{\mathrm{B}}\right)$, antagonistic; $\mathrm{SF}_{\mathrm{A}+\mathrm{B}}=\left(\mathrm{SF}_{\mathrm{A}}\right) \times\left(\mathrm{SF}_{\mathrm{B}}\right)$, additive; $\mathrm{SF}_{\mathrm{A}+\mathrm{B}}<\left(\mathrm{SF}_{\mathrm{A}}\right) \times\left(\mathrm{SF}_{\mathrm{B}}\right)$, synergistic; where $\mathrm{SF}$ is the surviving fraction; $\mathrm{A}$ and $\mathrm{B}$ indicate the agent when used alone, and $\mathrm{A}+\mathrm{B}$ refers to the agents when used in combination.

Cell cycle analysis. The cell cycle phase $\left(\mathrm{G}_{0}-\mathrm{G}_{1}, \mathrm{~S}\right.$ and $\left.\mathrm{G}_{2}-\mathrm{M}\right)$ distribution of the human colorectal cancer cells (SW48, SW1116 and SW837) was evaluated by measuring the DNA content of nuclei that were labeled with propidium iodide via flow cytometry (23). The human colorectal cancer cells were plated $\left(5 \times 10^{5} /\right.$ well) into 24 -well plates and incubated at $37^{\circ} \mathrm{C}$ in a non- $\mathrm{CO}_{2}$ incubator. After $18 \mathrm{~h}$, the cells were treated with either NaB (3 mM), MG115 $(1.0 \mu \mathrm{M})$, MG132 $(1.0 \mu \mathrm{M})$, PSI-1 $(0.1 \mu \mathrm{M})$, PSI-2 $(1.5 \mu \mathrm{M})$, epoxomicin $(12.0 \mathrm{nM})$, or with combinations of $\mathrm{NaB}$ and the proteasome inhibitors $[\mathrm{NaB} /$ MG115 (3.0 mM/1.0 $\mu \mathrm{M}), \mathrm{NaB} / \mathrm{MG} 132(3.0 \mathrm{mM} / 1.0 \mu \mathrm{M})$, NaB/PSI-1 (3.0 mM/0.1 $\mu \mathrm{M})$, PSI-2 (3.0 mM/1.5 $\mu \mathrm{M})$ and $\mathrm{NaB}$ /epoxomicin $(3.0 \mathrm{mM} / 12.0 \mathrm{nM})$ ] for $72 \mathrm{~h}$. The tested cells were collected via trypsinization then washed with cold phosphate-buffered saline and counted with a cell counter. A sample of $5 \times 10^{5} \mathrm{cell} / \mathrm{s} / \mathrm{ml}$ was processed using a DNA-Prep kit (Beckman and Coulter, FL, USA) and a DNA-Prep Epics workstation (Beckman and Coulter). During this process, the cell sample was treated with a cell membrane-premeabilizing agent, followed by the propidium iodide and RNase enzyme. The sample was then incubated at room temperature for at least 15 min before being analyzed by aligned flow cytometry (Epics XL, Beckman and Coulter). The percentage of cells in various cell cycle phases was calculated using the Phoenix statistical software package and advanced DNA cell cycle software (Phoenix Flow Systems, San Diego, CA, USA).

Acridine orange (AO) staining. Morphological evidence of apoptosis was obtained through the use of $\mathrm{AO} / \mathrm{ethidium}$ bromide (EB) staining. After removal of the incubation medium, cells were rinsed and treated with an AO/EB solution (100 $\mu \mathrm{g} / \mathrm{ml}$ PBS of each dye), then examined by fluorescence microscopy and photographed. Viable cells appeared green with intact nuclei, while nonviable cells exhibited bright orange chromatin. Apoptosis was marked by the appearance of cell shrinkage with condensation and the fragmentation of nuclei; in addition, apoptotic cells were easily distinguished from necrotic cells since the latter appeared orange and had a normal nuclear structure.

DNA fragmentation analysis. A DNA fragmentation assay was also performed (24). Human colorectal cancer cells were plated $\left(5 \times 10^{5} /\right.$ well) into 24 -well plates and incubated at $37^{\circ} \mathrm{C}$ in a non- $\mathrm{CO}_{2}$ incubator. After $18 \mathrm{~h}$, the cells were treated for $72 \mathrm{~h}$ with $\mathrm{NaB}(3.0 \mathrm{mM}), \mathrm{MG} 115(1.0 \mu \mathrm{M}), \mathrm{MG} 132(1.0 \mu \mathrm{M})$, PSI-1 $(0.1 \mu \mathrm{M})$, PSI-2 $(1.5 \mu \mathrm{M})$, epoxomicin $(12.0 \mathrm{nM})$, or the combinations of $\mathrm{NaB}$ and proteasome inhibitors that were previously mentioned. The cell pellets of SW48, SW1116 and SW837 cells were then lysed with $100 \mu \mathrm{M}$ of hypotonic buffer [10 mM Tris, (pH 8.0), $20 \mathrm{mM}$ EDTA containing $0.5 \%$ Triton X-100] for $30 \mathrm{~min}$ at $4^{\circ} \mathrm{C}$. After lysis, the intact chromatin (pellet) was separated from the DNA fragment (supernatant) by centrifugation for $15 \mathrm{~min}$ at $12,000 \mathrm{x} \mathrm{g}$. The supernatants containing fragmented DNA were precipitated overnight with $0.5 \mathrm{M} \mathrm{NaCl}$ and $50 \%$ isopropyl alcohol at $-20^{\circ} \mathrm{C}$. Pellets were recovered by centrifugation at $12,000 \mathrm{x} \mathrm{g}$ for $10 \mathrm{~min}$, air dried, then re-suspended in $30 \mu \mathrm{l}$ of TE-buffer supplemented with $1 \mathrm{mg} / \mathrm{ml}$ RNase I at $37^{\circ} \mathrm{C}$ for $30 \mathrm{~min}$ and again with $2 \mathrm{mg} / \mathrm{ml}$ of proteinase $\mathrm{K}$ for another $1 \mathrm{~h}$. A DNA sample was supplemented with $3 \mu \mathrm{l}$ of sample buffer $(0.25 \%$ Bromophenol blue, 30\% glyceric acid) and electrophoretically separated on a $1.0 \%$ agrose gel containing $0.1 \mu \mathrm{g} / \mathrm{ml}$ ethidium bromide. DNA fragments were then visualized using ultraviolet transillumination.

Western blot analysis of cell cycle and apoptosis regulatory protein expression levels in human colorectal cancer cells treated with proteasome inhibitors, NaB, and their combinations. The expression levels of cell cycle and apoptosis regulatory proteins were determined as follows (24): $1-2 \times 10^{6}$ human colorectal cells were treated with $\mathrm{NaB}$ (3.0 mM), MG115 (1.0 $\mu \mathrm{M}), \operatorname{MG} 132(1.0 \mu \mathrm{M})$, PSI-1 $(0.1 \mu \mathrm{M})$, PSI-2 $(1.5 \mu \mathrm{M})$, epoxomicin $(12.0 \mathrm{nM})$, or a combination of $\mathrm{NaB}$ and each of the proteasome inhibitors. The samples were washed twice with ice-cold phosphate-buffered saline then lysed for 30 min with a solution composed of 1\% NP40, $0.5 \%$ sodium deoxycholate, and $0.1 \%$ SDS in PBS (pH 7.4), then sonicated three times for $10 \mathrm{sec}$. The following protease inhibitors were added: $25 \mu \mathrm{g} / \mathrm{ml}$ aprotinin, $1 \mathrm{mM}$ phenylmethylsulfonyl fluoride, $1 \mathrm{mM}$ sodium orthovanadate, $10 \mathrm{mM}$ $\mathrm{NaF}, 25 \mu \mathrm{g} / \mathrm{ml}$ leupeptin and $0.2 \mathrm{mM}$ sodium PPi. Cell lysates were centrifuged at $15,000 \mathrm{x} \mathrm{g}$ for $20 \mathrm{~min}$ at $4^{\circ} \mathrm{C}$; equivalent amounts of protein $(60 \mu \mathrm{g})$ were resolved by $10 \%$ SDS-PAGE and transferred onto nitrocellulose for detection with antibodies. The primary antibodies used were: goat polyclonal anti-human Bax (1:500), CPP32 (1:1000), lamin B (1:1000), rabbit polyclonal anti-human PARP (1:2000), mouse monoclonal anti-human BcL2 (1:1000), p53 (1:1000); p21 Waf1 (1:500), p27 Kip1 (1:500) and $\beta$-actin (1:1000). Visualization was performed using nitroblue tetrazolium and bromochloroindoyl-phosphate. The specificities of the antibodies used in this study were examined by testing their reactivities with unrelated antigens, such as bovine serum albumin (BSA). The blots were scanned, and the band intensities were determined using Master ${ }^{\mathrm{TM}}$ Total Lab Software v. 2.0 (Amersham Biosciences, UK). Expression of p53, p21 ${ }^{\text {Waf1 }}$, p27 ${ }^{\text {Kip1 }}$, and Bax and BcL2 genes was calculated by setting the $\beta$-actin protein at $100 \%$ and calculating the expression of these genes in relation to this internal standard.

In vitro assay of caspase-3 activity. The catalytic activity of caspase-3 was measured using a colorimetric assay according to the manufacturer's (Calbiochem) instructions. the assay is based on spectrophotometric detection of the chromophore $p$-nitroanilide following cleavage from the labeled substrate of the enzyme DEVD-p-nitroanilide. Human colorectal cancer cells were treated with $\mathrm{NaB}(3.0 \mathrm{mM})$, epoxomicin $(12 \mathrm{nM})$, or a combination of $\mathrm{NaB}(3.0 \mathrm{mM})$ and epoxomicin $(12 \mathrm{nM})$ for $24 \mathrm{~h}$, and then harvested by centrifugation at $1,000 \mathrm{x} \mathrm{g}$ for $10 \mathrm{~min}$. The cells were then washed twice with ice-cold PBS. The cell pellet was re-suspended in $100 \mu$ l of extraction buffer that contained $50 \mathrm{mM}$ HEPES, $1 \mathrm{mM}$ DDT, $0.1 \mathrm{mM}$ EDTA, $10 \%$ glycerol and $0.1 \%$ CHAPS at a $\mathrm{pH}$ of 7.4 . After $10 \mathrm{~min}$ 

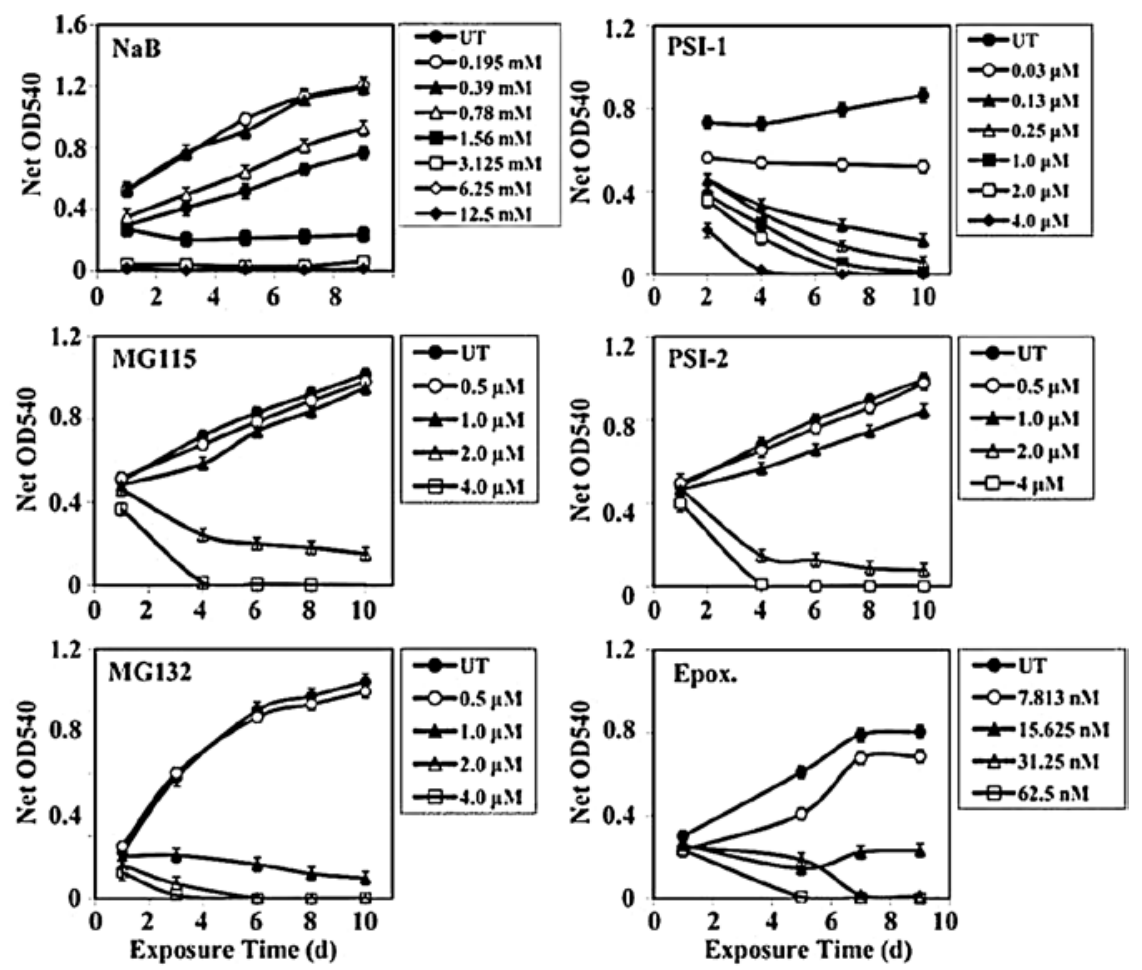

Figure 1. Time- and dose-dependent antiproliferative effects of proteasome inhibitors and NaB on human colorectal cancer cells. Human colorectal cancer SW837 cells were plated $\left(27 \times 10^{3}\right.$ cells/well) into 96 -well plates and incubated at $37^{\circ} \mathrm{C}$ in a non- $\mathrm{CO}_{2}$ incubator. After $18 \mathrm{~h}$, the cells were treated with various concentrations of NaB (0-12.5 mM), MG115 (0.06-4.0 $\mu \mathrm{M})$, MG132 (0.06-4.0 $\mu \mathrm{M})$, PSI-1 (0.03-4.0 $\mu \mathrm{M})$, PSI-2 (0.03-4.0 $\mu \mathrm{M})$ and epoxomicin (7.8-62.5 nM) for different periods of time. The cell growth was measured by an MTT assay.

of incubation on ice, the cells were centrifuged at $10,000 \mathrm{x} \mathrm{g}$ at $4^{\circ} \mathrm{C}$ for $10 \mathrm{~min}$, and the supernatants were removed and stored at $-70^{\circ} \mathrm{C}$. Proteolytic reactions were carried out in an assay buffer [50 mM HEPES (pH 7.4), $100 \mathrm{mM} \mathrm{NaCl,} \mathrm{0.1} \mathrm{CHAPS,}$ $10 \mathrm{mM}$ dithiothreitol, $0.1 \mathrm{mM}$ EDTA and $10 \%$ glycerol] containing $20 \mu \mathrm{g}$ of cytosolic protein extracts, and incubated at $37^{\circ} \mathrm{C}$ for $10 \mathrm{~min}$. Thereafter, a freshly prepared colorimetric substrate was added to the mixtures, and the samples were mixed and recorded according to the manufacturer's instructions. Cells without drug treatment were used as controls. Enzyme activity was calculated as pmol/min, according to the formula provided by the manufacturer.

Inhibition of caspase-3 activity. Inhibition of caspases with DEVD cleavage activity was achieved using the inhibitors Ac-DEVD $(500 \mu \mathrm{M})$ and $\mathrm{z}$-VAD-fmk $(100 \mu \mathrm{M})$ that were administered $1 \mathrm{~h}$ before the addition of either $3 \mathrm{mM} \mathrm{NaB}$ or $12 \mathrm{nM}$ epoxomicin. Twenty-four hours after the addition of $\mathrm{NaB}$ or epoxomicin, the cells were harvested and analyzed for caspase-3 activity.

In vitro assay of cytochrome-c efflux from the mitochondria. Subcellular fractions were prepared as described by Yang et al (25). The human colorectal cells $\left(1-2 \times 10^{6}\right)$ were treated with $\mathrm{NaB}(3.0 \mathrm{mM})$, epoxomicin $(12.0 \mathrm{nM})$, or a combination of $\mathrm{NaB}(3.0 \mathrm{mM})$ and epoxomicin $(12.0 \mathrm{nM})$. The cells were washed twice in PBS and re-suspended in a lysis buffer [20 mM HEPES-KOH (pH 7.5), $10 \mathrm{mM} \mathrm{KCl,} 1.5 \mathrm{mM} \mathrm{MgCl}_{2}$, $1 \mathrm{mM}$ EGTA, $1 \mathrm{mM}$ EDTA, $1 \mathrm{mM}$ DTT and $0.1 \mathrm{mM}$ phenylmethylsulfonyl fluoride] containing $250 \mathrm{mM}$ sucrose. The cells were homogenized with 20 strokes of Teflon homogenizers, and the homogenates were centrifuged at $750 \mathrm{x} \mathrm{g}$ for $10 \mathrm{~min}$ at $4^{\circ} \mathrm{C}$; the resulting supernatants were centrifuged at $10,000 \mathrm{x} \mathrm{g}$ for $30 \mathrm{~min}$. The mitochondrial pellets were re-suspended in the same buffer. The cytosolic fraction was obtained after centrifugation at $100,000 \mathrm{x}$ g for $1 \mathrm{~h}$ at $4^{\circ} \mathrm{C}$. For the immunoblotting analysis, equal amounts of protein $(50 \mu \mathrm{g})$ were subjected to a $10 \%$ SDS-PAGE. After being transferred to a nitrocellulose filter, the filter was probed using the mouse monoclonal anti-human cytochrome- $c$ antibody (1:1000).

Statistical analysis. The data were recorded as the mean $\pm \mathrm{SE}$ and were analyzed by SPSS (version 10, SPSS Inc.). One-way analysis of variance was performed using the ANOVA procedure. Significant differences between the means of percentage growth inhibition were determined by least significant difference (LSD), and differences were considered statistically significant at $\mathrm{P}<0.05$.

\section{Results}

Time- and dose-dependent antiproliferative effect of proteasome inhibitors and $\mathrm{NaB}$ on human colorectal cancer cells. Human colorectal cancer SW837 cells treated with various concentrations of $\mathrm{NaB}$ or the proteasome inhibitors, MG115, MG132, PSI-1, PSI-2 and epoxomicin, showed marked timeand dose-dependent growth inhibition (Fig. 1). Treatment of SW837 cells with low concentrations of $\mathrm{NaB}(0.195-0.78 \mathrm{mM})$ had no effect on their growth. But when SW837 cells were treated with $1.56 \mathrm{mM} \mathrm{NaB}$, higher growth inhibition (mean 

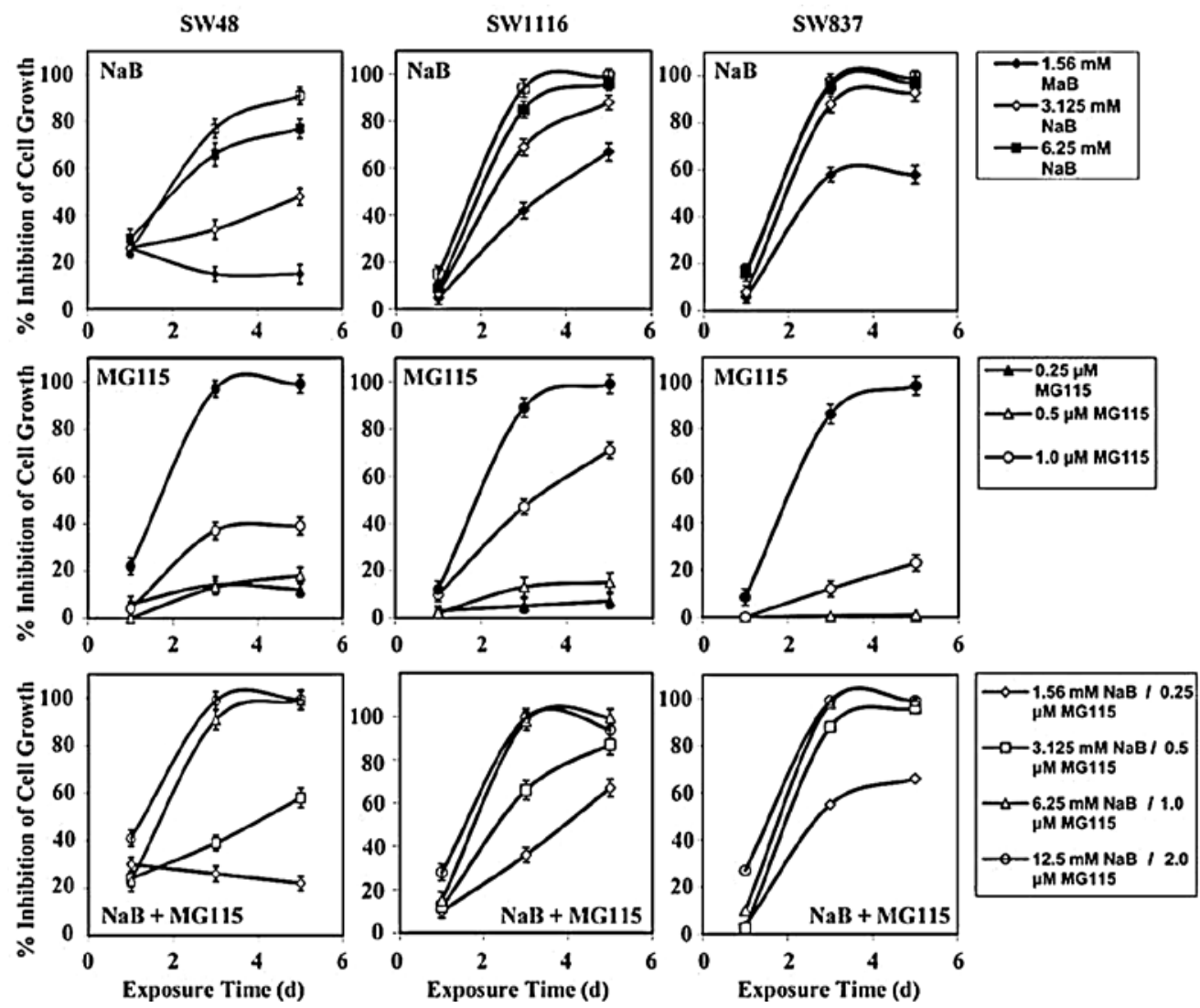

Figure 2. Enhancement of the anticancer effects of proteasome inhibitor MG115 with NaB on human colorectal cancer cells. Human colorectal cancer cells, SW48, SW1116 and SW837 were plated $\left(27 \times 10^{3}\right.$ cells/well) into 96 -well plates and incubated at $37^{\circ} \mathrm{C}$ in a non- $\mathrm{CO}_{2}$ incubator. After $18 \mathrm{~h}$, cells were treated individually with $\mathrm{NaB}(1.56-12.5 \mathrm{mM})$ and MG115 $(0.25-2.0 \mu \mathrm{M})$ or with the combinations of NaB/MG115 $(1.56 \mathrm{mM} / 0.25 \mu \mathrm{M} ; 3.125 \mathrm{mM} / 0.5 \mu \mathrm{M}$; $6.25 \mathrm{mM} / 1.0 \mu \mathrm{M} ; 12.5 \mathrm{mM} / 2.0 \mu \mathrm{M}$ ), starting $18 \mathrm{~h}$ after seeding the cells in culture. Control cells were left untreated or treated with vehicle (DMSO at a final concentration $0.1 \%$ ).

percentage growth inhibition, $51.2 \pm 10 \%$ ) was observed. Marked growth inhibition (mean, $96 \pm 0.95 \%$ ) was noted when the SW837 cells were treated with even higher concentrations of $\mathrm{NaB}$ (3.125-12.5 mM) (Fig. 1).

The growth of SW837 cells was slightly affected (mean, $10 \pm 2 \%)$ after treatment with proteasome inhibitor MG115 (0.5-1.0 $\mu \mathrm{M})$. Treatment of SW837 cells with higher concentrations of MG115 (2.0-4.0 $\mu \mathrm{M})$ produced $17.5 \pm 0.9 \%$ growth inhibition after $24 \mathrm{~h}$; however, a much higher growth inhibition $(87 \pm 5 \%)$ was noticed after $96-240 \mathrm{~h}$ of treatment with MG115 (2.0-4.0 $\mu \mathrm{M})$ (Fig. 1).

The growth of SW837 cells was slightly affected (mean, $26 \pm 9 \%$ ) after $24 \mathrm{~h}$ of treatment with 1.0-4.0 $\mu \mathrm{M}$ of MG132. A marked growth inhibitory effect (mean, 92 $3 \%$ ) was observed with longer periods of treatment $(72-240 \mathrm{~h})$ with the same range of MG132 concentrations (1.0-4.0 $\mu \mathrm{M})$ (Fig. 1).

Treatment of SW837 cells with $0.03 \mu \mathrm{M}$ PSI-1 inhibited their growth by $31 \pm 4 \%$. Increasing concentrations of PSI-1 (0.13-0.25 $\mu \mathrm{M})$ produced a higher growth inhibition $(65 \pm 7 \%)$. An even higher growth inhibition (mean, $83 \pm 6 \%$ ) was obtained with higher concentrations of PSI-1 (1.0-4.0 $\mu \mathrm{M})$ (Fig. 1).

The growth of SW837 cells was slightly affected (mean, $9 \pm 2 \%$ ) after treatment with PSI-2 at 0.5-1.0 $\mu \mathrm{M}$. However, the growth of SW837 cells was dramatically inhibited (mean, $93 \pm 3 \%$ ) after $96-240$ h of treatment with higher concentrations of PSI-2 (2.0-4.0 $\mu \mathrm{M})$ (Fig. 1).
Treatment of SW837 cells with a low concentration of epoxomicin $(7.8 \mathrm{nM})$ slightly affected (mean, $21 \pm 4 \%$ ) their growth throughout $24-240 \mathrm{~h}$ of treatment. A similar degree of inhibition (mean, 22.8 $\pm 3 \%$ ) was obtained when SW837 cells were treated with higher concentrations (15.6-250 nM) for $24 \mathrm{~h}$. However, a marked growth inhibition (mean, 92 $\pm 3 \%$ ) was obtained when SW837 cells were exposed to $15.6-250 \mathrm{nM}$ of epoxomicin for 120-216 h (Fig. 1).

Augmentation of the antimitogenic effect of proteasome inhibitors by combination with $\mathrm{NaB}$ in human colorectal cancer cells

Augmentation of the anticancer effect of proteasome inhibitor MG115 by combination with NaB in colorectal cancer cells. Treatment of human colorectal cancer SW48 cells with NaB, MG115, and their combination inhibited their growth by $26.8 \pm 2,8.0 \pm 0.97$ and $29.75 \pm 0.8 \%$, respectively, after $24 \mathrm{~h}$ of treatment (Fig. 2). The differences in growth inhibition between the combined treatment and single treatment with $\mathrm{NaB}(\mathrm{P}=0.899)$ and MG115 $(\mathrm{P}=0.314)$ were statistically nonsignificant.

Treatment of SW48 with NaB, MG115, and their combination inhibited their growth by $47.5 \pm 3,38 \pm 4$ and $63 \pm 3.8 \%$, respectively, after $72 \mathrm{~h}$ of treatment. Although the combined treatment netted a higher growth inhibition than single treat- 

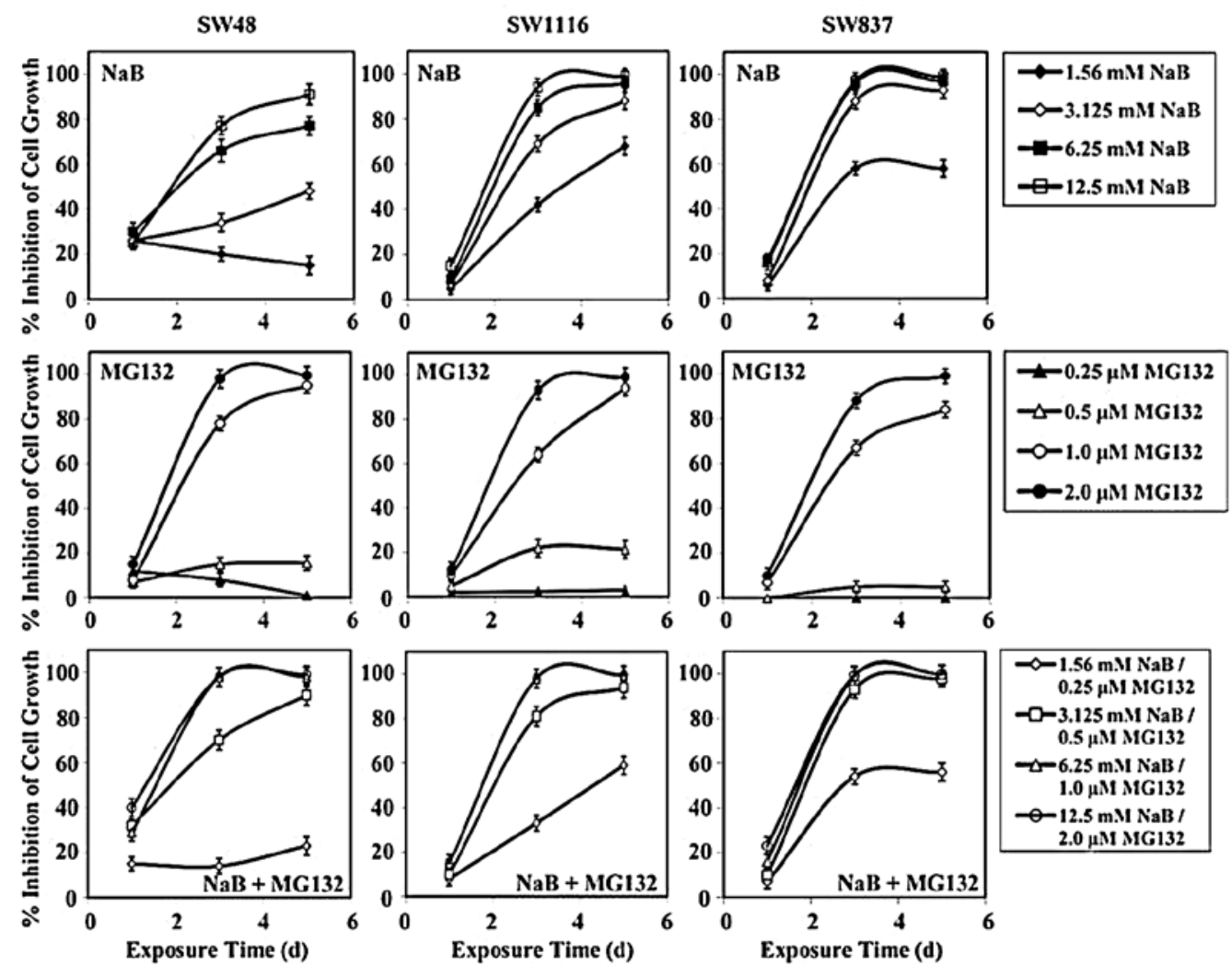

Figure 3. Enhancement of the anticancer effects of proteasome inhibitor MG132 with NaB on human colorectal cancer cells. Human colorectal cancer cells, SW48, SW1116 and SW837, were plated $\left(27 \times 10^{3}\right.$ cells/well) into 96-well plates and incubated at $37^{\circ} \mathrm{C}$ in a non- $\mathrm{CO}_{2}$ incubator. After $18 \mathrm{~h}$, cells were treated individually with $\mathrm{NaB}(1.56-12.5 \mathrm{mM})$ and MG132 $(0.25-2.0 \mu \mathrm{M})$ or with the combinations of NaB/MG132 (1.56 mM/0.25 $\mu \mathrm{M} ; 3.125 \mathrm{mM} / 0.5 \mu \mathrm{M} ; 6.25 \mathrm{mM} / 1.0 \mu \mathrm{M}$; $12.5 \mathrm{mM} / 2.0 \mu \mathrm{M}$ ), starting $18 \mathrm{~h}$ after seeding the cells in culture. Control cells were left untreated or treated with vehicle (DMSO at a final concentration $0.1 \%$ ).

ment with $\mathrm{NaB}(\mathrm{P}=0.418)$ or MG115 $(\mathrm{P}=0.303)$, the differences in growth inhibition were non-significant. The combined treatment of SW48 with NaB and MG115 netted a higher growth inhibition (mean percentage growth inhibition, $70 \pm 3.1 \%$ ) than single treatment with $\mathrm{NaB}$ (mean percentage growth inhibition, $58 \pm 5 \%$ ) and MG115 (mean percentage growth inhibition, $42 \pm 3 \%$ ) after $120 \mathrm{~h}$ of treatment. The differences in growth inhibition of SW48 between combined treatment and single treatment with $\mathrm{NaB}(\mathrm{P}=0.584)$ and $\mathrm{MG} 115(\mathrm{P}=0.206)$ were statistically non-significant.

Treatment of SW1116 cells with NaB, MG115, and their combination had very little effect on their growth after $24 \mathrm{~h}$ of treatment (Fig. 2). However, higher growth inhibition was observed when SW1116 cells were treated for a longer period (72 h) with $\mathrm{NaB}$ (mean, 72.5 $\pm 2.3 \%$ ), MG115 (mean, 39 $\pm 4 \%$ ), and the combination of $\mathrm{NaB}$ and MG115 (mean, $75 \pm 3 \%$ ). The combined treatment produced a significant growth inhibition effect $(\mathrm{P}=0.05)$ on $\mathrm{SW} 1116$, as compared to single treatment with MG115. However, the difference in growth inhibition of SW1116 exerted by combined treatment, as compared to that produced by $\mathrm{NaB}$, was statistically non-significant $(\mathrm{P}=0.9)$. Treatment of SW1116 with the combination of NaB and MG115 for an even longer period $(120 \mathrm{~h})$ produced marked growth inhibition (mean, $87 \pm 14 \%$ ), as compared to that produced by treatment with MG115 (mean, 43 $\pm 5 \%$ ). The difference between the growth inhibition produced by combined treatment and MG115 was statistically very significant $(\mathrm{P}=0.024)$. Treatment of SW1116 with $\mathrm{NaB}$ for 120 h gave comparable growth inhibition (mean, $87.7 \pm 14 \%$ ) to that produced by combined treatment for $120 \mathrm{~h}$ (Fig. 2).

Treatment of SW837 cells with NaB, MG115, and their combination for $24 \mathrm{~h}$ produced very small growth inhibitory effects (mean, $6 \pm 0.4 \%$ ) (Fig. 2). However, after $72 \mathrm{~h}$ of treatment, NaB markedly inhibited the growth of SW837 cells (mean, $84 \pm 2 \%$ ). On the other hand, MG115 produced a moderate growth inhibition (mean, $31 \pm 4 \%$ ). The growth inhibition of SW837 cells (mean, $85 \pm 2 \%$ ) produced by the combination of $\mathrm{NaB}$ and MG115 was comparable to that produced by NaB. Inhibition of SW837 cells by the combination of $\mathrm{NaB}$ and MG115 was statistically very significant $(\mathrm{P}=0.004)$, as compared to the inhibition produced by single treatment with MG115 for $72 \mathrm{~h}$. Treatment of SW837 cells with $\mathrm{NaB}$ for $120 \mathrm{~h}$ produced growth inhibition (mean, $90 \pm 2 \%$ ) comparable to that produced by single treatment with $\mathrm{NaB}$ (mean, $87 \pm 2 \%$ ). In contrast, MG115 produced moderate growth inhibition (mean, 31 $\pm 5 \%$ ) after $120 \mathrm{~h}$ of treatment. Inhibition of SW837 cell growth produced by the combination of $\mathrm{NaB}$ and MG115 was statistically very significant $(\mathrm{P}=0.002)$, as compared to that produced by MG115 after $120 \mathrm{~h}$ of treatment.

Augmentation of the antimitogenic effect of proteasome inhibitor MG132 by combination with $\mathrm{NaB}$ in colorectal cancer cells. Treatment of human colorectal cancer SW48 cells for $24 \mathrm{~h}$ with $\mathrm{NaB}, \mathrm{MG132}$, and their combination inhibited cell growth by $27 \pm 2,11 \pm 3$ and $29 \pm 56 \%$, respectively (Fig. 3). 
SW 48
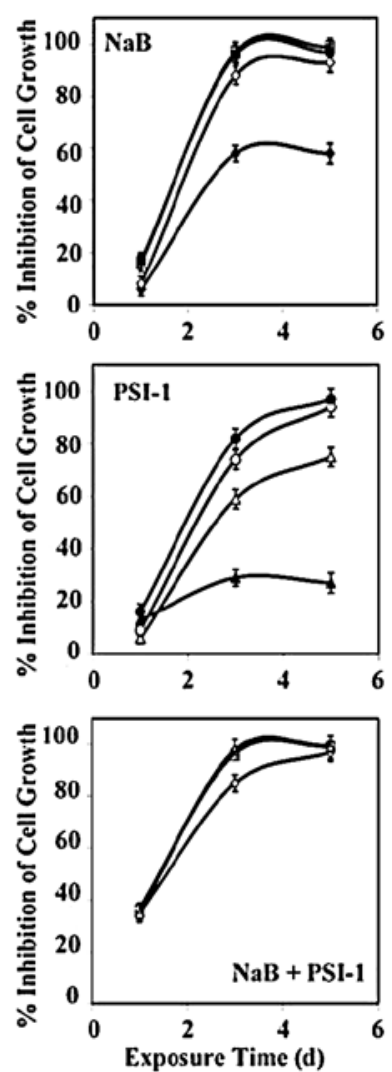

SW1116
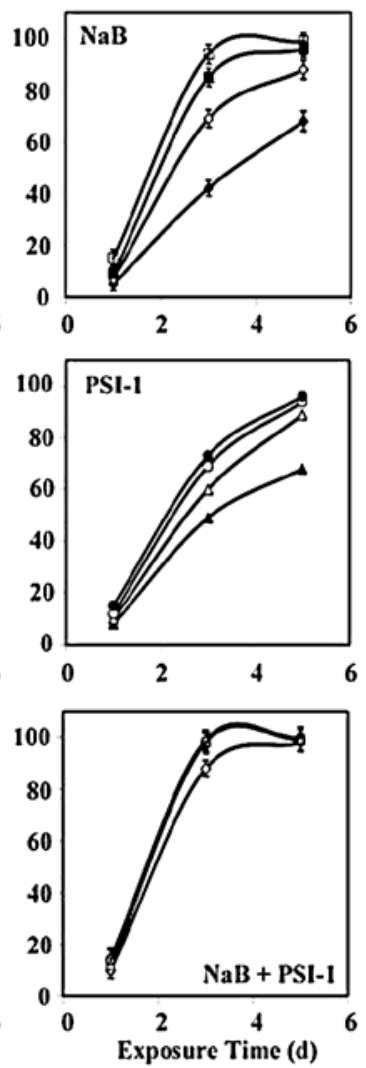

SW837
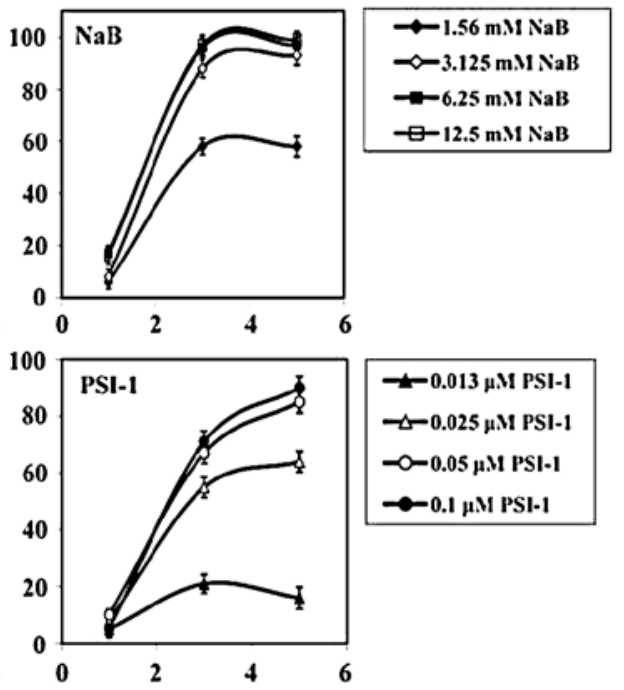

$\sim 0.05 \mu \mathrm{M}$ PSI.1

$\rightarrow 0.1 \mu \mathrm{MPSI}-1$

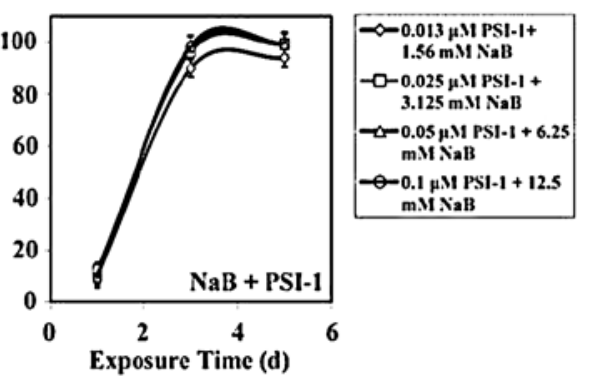

Figure 4. Enhancement of the anticancer effects of proteasome inhibitor-1 with NaB on human colorectal cancer cells. Human colorectal cancer cells, SW48, SW1116 and SW837, were plated $\left(27 \times 10^{3}\right.$ cells/well) into 96-well plates and incubated at $37^{\circ} \mathrm{C}$ in a non- $\mathrm{CO}_{2}$ incubator. After $18 \mathrm{~h}$, cells were treated individually with NaB (1.56-12.5 mM) and PSI-1 (0.013-0.1 $\mu \mathrm{M})$ or with the combinations of NaB/PSI-1 (1.56 mM/0.013 $\mu \mathrm{M} ; 3.125 \mathrm{mM} / 0.025 \mu \mathrm{M} ; 6.25 \mathrm{mM} / 0.05 \mu \mathrm{M}$; $12.5 \mathrm{mM} / 0.1 \mu \mathrm{M})$, starting $18 \mathrm{~h}$ after seeding the cells in culture. Control cells were left untreated or treated with vehicle (DMSO at a final concentration $0.1 \%$ ).

The differences in the growth inhibition produced by the combination of $\mathrm{NaB}$ and $\mathrm{MG} 132$ compared to that produced by $\mathrm{NaB}(\mathrm{P}=0.923)$ or MG132 $(\mathrm{P}=0.428)$ were statistically nonsignificant. After $72 \mathrm{~h}$ of treatment with $\mathrm{NaB}, \mathrm{MG} 132$, or their combination, the growth of SW48 cells was inhibited by $48 \pm 3$, $50 \pm 5$ and $70 \pm 4 \%$, respectively (Fig. 3). Although the combination of $\mathrm{NaB}$ and MG132 produced a higher growth inhibition than single treatment with $\mathrm{NaB}(\mathrm{P}=0.34)$ and MG132 $(\mathrm{P}=0.39)$, the differences were non-significant. Additionally, combined treatment produced a higher growth inhibition (mean, $78 \pm 4 \%$ ), as compared to single treatment of $\mathrm{NaB}$ (mean, $58 \pm 3 \%$ ) and MG132 (mean, $55 \pm 5 \%$ ) after $120 \mathrm{~h}$ of treatment. However, the differences in growth inhibition between combined treatment and $\mathrm{NaB}(\mathrm{P}=0.4)$ and MG132 $(\mathrm{P}=0.33)$ were statistically nonsignificant after $120 \mathrm{~h}$ of treatment.

Treatment of SW1116 cells with NaB, MG132, and their combination had very little effect on the growth of SW1116 cells after $24 \mathrm{~h}$ of treatment (Fig. 3). However, after $72 \mathrm{~h}$ of treatment, the combination of $\mathrm{NaB}$ and MG132 produced a higher growth inhibition (mean, $78 \pm 3 \%$ ) than single treatment with MG132 (mean, 46 $\pm 4 \%$ ). This difference in growth inhibition was statistically non-significant $(\mathrm{P}=0.1)$. NaB had similar growth inhibition (mean, $73 \pm 2 \%$ ) to that produced by combined treatment (Fig. 3). After $120 \mathrm{~h}$ of treatment, the combination of $\mathrm{NaB}$ and MG132 produced a higher growth inhibition (mean, $88 \pm 2 \%$ ) than single treatment with MG132 (mean, 54 $\pm 5 \%$ ). The difference in SW1116 growth inhibition was statistically significant $(\mathrm{P}=0.05)$. NaB produced comparable growth inhibition (mean, $88 \pm 4 \%$ ) to that produced by combined treatment (Fig. 3).

The growth of human colorectal cancer cells SW837 was slightly affected when treated with $\mathrm{NaB}$, MG132, or their combination for $24 \mathrm{~h}$ (Fig. 3). However, the growth of SW837 cells was markedly affected by the combination of $\mathrm{NaB}$ and MG132 (mean, $86 \pm 2 \%$ ) after $72 \mathrm{~h}$ of treatment. $\mathrm{NaB}$ produced growth inhibition (mean, $84 \pm 2 \%$ ) similar to that of the combined treatment. However, much less growth inhibition was observed when SW837 cells were treated

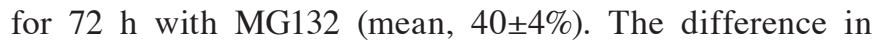
the growth inhibition of SW837 after treatment with the combination of $\mathrm{NaB}$ and MG132 and single treatment with MG132 was statistically significant $(\mathrm{P}=0.022)$. Treatment of SW837 cells with the combination of $\mathrm{NaB}$ and MG132 for $120 \mathrm{~h}$ produced a marked growth inhibition (mean, $89 \pm 2 \%$ ). $\mathrm{NaB}$ produced growth inhibition of SW837 (mean, $87 \pm 2 \%$ ) similar to that produced by the combination of $\mathrm{NaB}$ and MG132 after $120 \mathrm{~h}$ of treatment. Much less growth inhibition

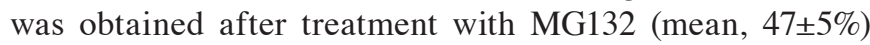
for $120 \mathrm{~h}$. The difference in the growth inhibition of SW837 cells produced by the combination of $\mathrm{NaB}$ and MG132 was statistically significant $(\mathrm{P}=0.037)$, when compared to single treatment with MG132. 
SW48
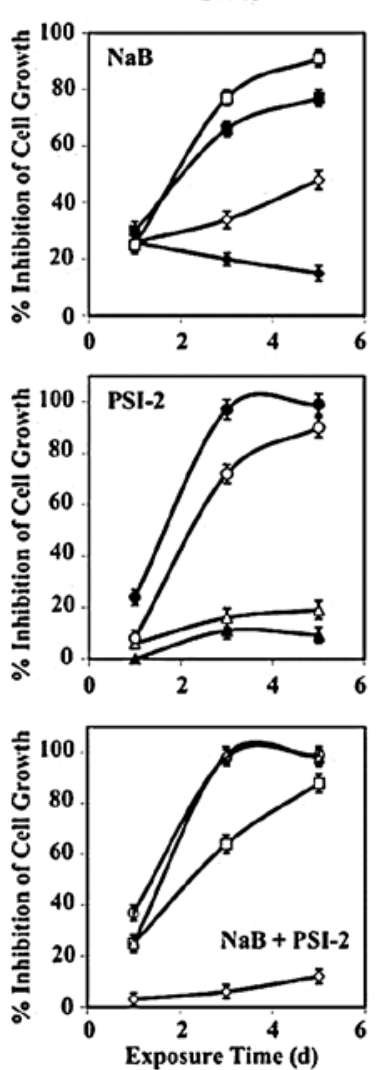

SW1116
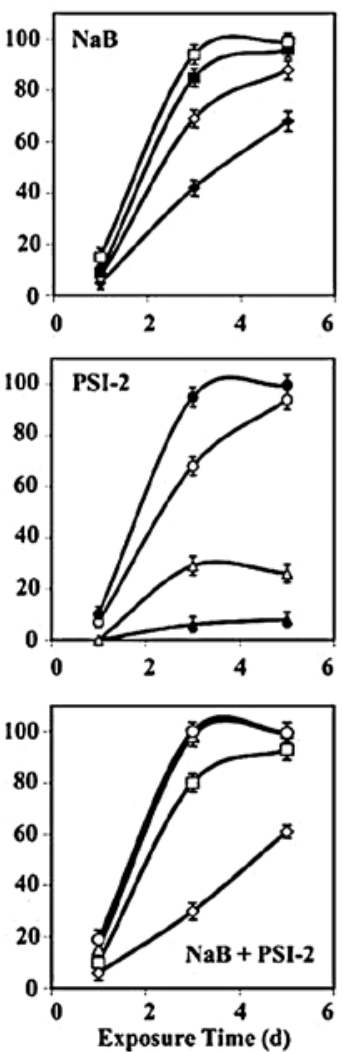

Sw837
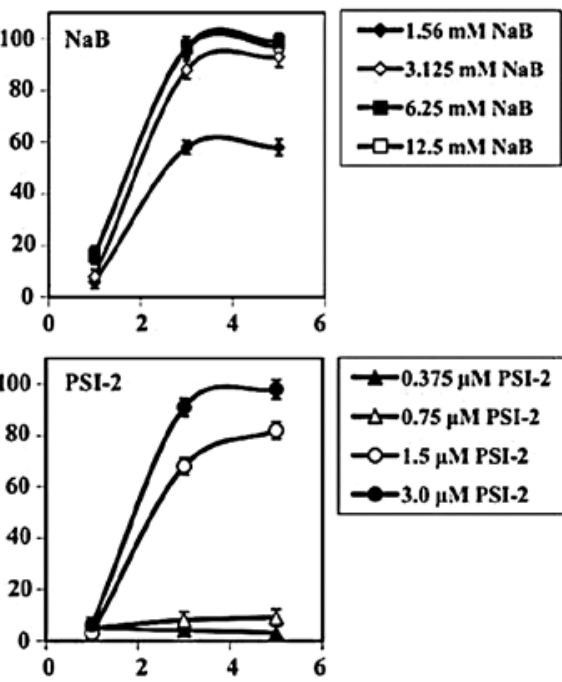

$\checkmark-0.75 \mu$ M PSI-2

$-1.5 \mu \mathrm{M}$ PSI.-

$-3.0 \mu \mathrm{M}$ PSI-2

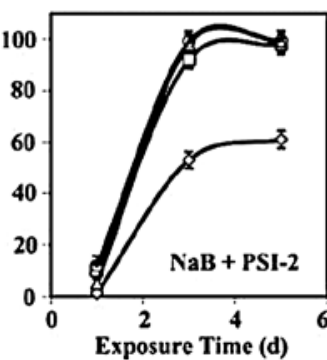

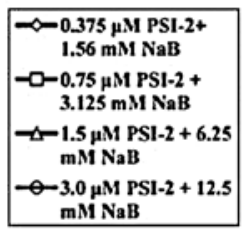

$\mathrm{mM} \mathrm{NaB}$

Figure 5. Enhancement of the anticancer effects of proteasome inhibitor-2 with NaB on human colorectal cancer cells. Human colorectal cancer cells, SW48, SW1116 and SW837, were plated $\left(27 \times 10^{3}\right.$ cells/well) into 96 -well plates and incubated at $37^{\circ} \mathrm{C}$ in a non- $\mathrm{CO}_{2}$ incubator. After 18 h, cells were treated individually with $\mathrm{NaB}(1.56-12.5 \mathrm{mM})$ and PSI-2 (0.375-3.0 $\mu \mathrm{M})$ or with the combinations of NaB/PSI-2 (1.56 mM/0.375 $\mu \mathrm{M} ; 3.125 \mathrm{mM} / 0.75 \mu \mathrm{M}$; $6.25 \mathrm{mM} / 1.5 \mu \mathrm{M} ; 12.5 \mathrm{mM} / 3.0 \mu \mathrm{M})$, starting $18 \mathrm{~h}$ after seeding the cells in culture. Control cells were left untreated or treated with vehicle (DMSO at a final concentration $0.1 \%$ ).

Augmentation of the antimitogenic effect of proteasome inhibitor PSI-1 by combination with NaB. Treatment of SW48 cells with the combination of $\mathrm{NaB}$ and PSI-1 for $24 \mathrm{~h}$ produced a growth inhibition of $36 \pm 0.8 \%$, while single treatment with $\mathrm{NaB}$ and PSI-1 produced a growth inhibition of $27 \pm 2$ and $11 \pm 4 \%$, respectively. After $72 \mathrm{~h}$ of treatment, the combination of $\mathrm{NaB}$ and PSI-1 produced a greater inhibition of SW48 growth (mean, $94 \pm 6 \%$ ) than single treatment with $\mathrm{NaB}$ (mean, $48 \pm 3 \%, \mathrm{P}=0.003$ ) and PSI-1 (mean, $61 \pm 2 \%$; $\mathrm{P}=0.03)$. Treatment of SW48 with the combination of $\mathrm{NaB}$ and PSI-1 for $120 \mathrm{~h}$ produced a marked growth inhibition (mean, 99 $\pm 1 \%$ ), as compared to single treatment with $\mathrm{NaB}$ (mean, 58 $\pm 3 \% ; \mathrm{P}=0.008$ ) and PSI-1 (mean, 73 $\pm 3 \%$; $\mathrm{P}=0.085$ ) (Fig. 4).

Treatment of human colorectal cancer cells SW1116 with $\mathrm{NaB}$, PSI-1, and their combination for $24 \mathrm{~h}$ had no effect on their proliferation. However, after $72 \mathrm{~h}$ of treatment, SW1116 cell growth was markedly inhibited (mean, 96 $\pm 7 \%$ ), as compared to single treatment with $\mathrm{NaB}$ (mean, $73 \pm 2 \%$ ) and PSI-1 (mean, $63 \pm 1 \%$ ). The differences in the growth inhibition produced by the combination of $\mathrm{NaB}$ and PSI-1 after $72 \mathrm{~h}$ of treatment and $\mathrm{NaB}(\mathrm{P}=0.005)$ or PSI-1 $(\mathrm{P}=0.001)$ were statistically very significant. After $120 \mathrm{~h}$, the combined treatment produced a slightly higher growth inhibition (mean, $99 \pm 1.0 \%$ ) than $\mathrm{NaB}$ (mean, $88 \pm 4 \%$ ) or PSI-1 (mean, $87 \pm 3 \%$ ) (Fig. 4).
The growth of human colorectal cancer SW837 cells was slightly affected after $24 \mathrm{~h}$ of treatment with $\mathrm{NaB}$ (mean, $12 \pm 1.0 \%$ ), PSI- 1 (mean, $1.3 \pm 0.4 \%$ ), and their combination

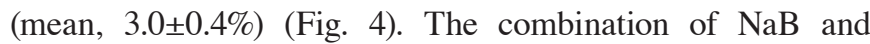
PSI-1 produced a marked growth inhibition of SW837 (mean, $96.0 \pm 4.0 \%$ ), as compared to that produced by PSI-1 (mean, $54.0 \pm 2.0 \%$ ) after $72 \mathrm{~h}$ of treatment. The difference in SW837 growth inhibition produced by combined treatment and single treatment with PSI-1 was statistically very significant $(\mathrm{P}=0.001)$. The combined treatment produced a higher growth inhibition

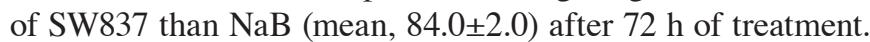
However, the difference in SW837 growth inhibition between these treatments was statistically non-significant $(\mathrm{P}=0.322)$. Similar results were obtained when SW837 cells were treated for $120 \mathrm{~h}$. The combined treatment produced greater significant growth inhibition (mean, $98.0 \pm 3.0 \%$ ), as compared to that produced by PSI-1 (mean, $64.0 \pm 3.0 \%, \mathrm{P}=0.006$ ). Additionally, the combined treatment produced higher SW837 growth inhibition, as compared to that produced by single treatment with $\mathrm{NaB}$ (mean, 87.0 $2.0 \%$ ). However, the difference in SW837 growth inhibition between these treatments was statistically non-significant $(\mathrm{P}=0.322)$ (Fig. 4).

Augmentation of the antimitogenic effect of PSI-2 by combination with NaB. Treatment of human colorectal 
SW48
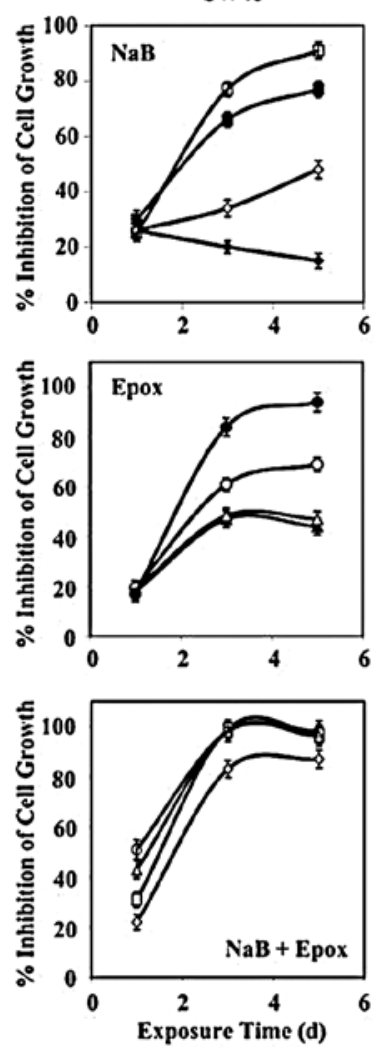

Sw1116
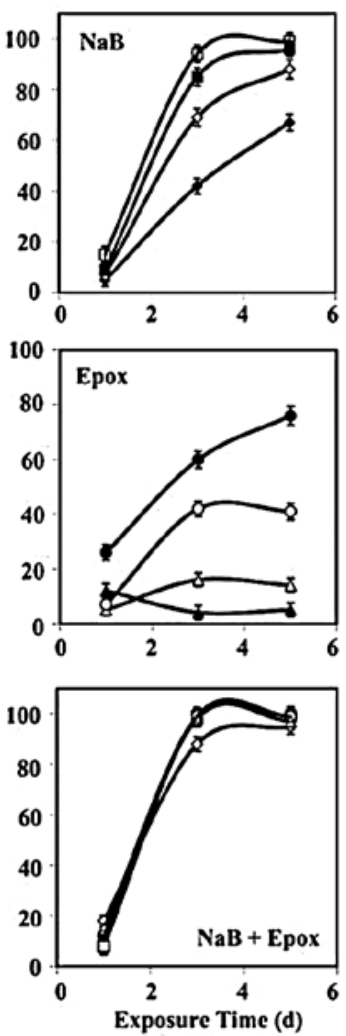

SW837
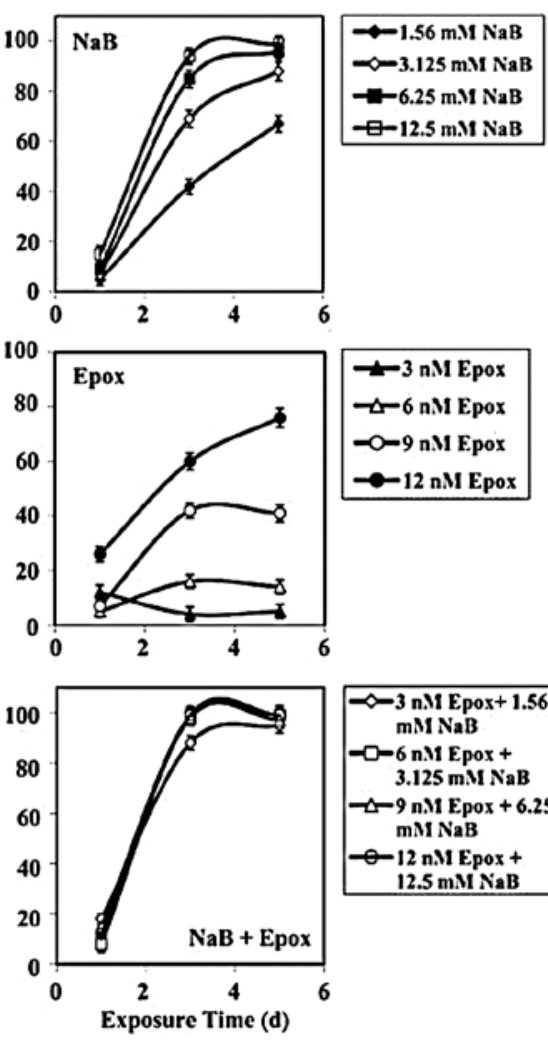

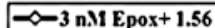

$\mathrm{mMNaB}$

$-0-6$ n.1 Epox +

$3.125 \mathrm{mM} \mathrm{NaB}$

$-\checkmark-9$ n.1 Epox +6.25

$12.5 \mathrm{mMNaB}$

Figure 6. Enhancement of the anticancer effects of proteasome inhibitor epoxomicin with NaB on human colorectal cancer cells. Human colorectal cancer cells, SW48, SW1116 and SW837, were plated (27x10 cells/well) into 96-well plates and incubated at $37^{\circ} \mathrm{C}$ in a non-CO incubator. After 18 h, cells were treated individually with $\mathrm{NaB}(1.56-12.5 \mathrm{mM})$ and epoxomicin (3.0-12.0 nM) or with the combinations of NaB/epoxomicin (1.56 mM/3.0 $\mathrm{nM} ; 3.125 \mathrm{mM} / 6 \mathrm{nM}$; $6.25 \mathrm{mM} / 9.0 \mathrm{nM} ; 12.5 \mathrm{mM} / 12.0 \mathrm{nM})$, starting $18 \mathrm{~h}$ after seeding the cells in culture. Control cells were left untreated or treated with vehicle (DMSO at a final concentration $0.1 \%$ ).

cancer SW48 cells with the combination of $\mathrm{NaB}$ and PSI-2 produced comparable growth inhibition (mean, $31 \pm 5 \%$ ) to that produced by $\mathrm{NaB}$ (mean, $27 \pm 2 \%$ ) after $24 \mathrm{~h}$ of treatment. The combined treatment produced higher growth inhibition than that produced by PSI-2 (mean, $10 \pm 1 \%$ ) after $24 \mathrm{~h}$ of treatment. However, this difference in growth inhibition was statistically non-significant $(\mathrm{P}=0.376)$ (Fig. 5). After $72 \mathrm{~h}$ of treatment, the combination of $\mathrm{NaB}$ and PSI-2 produced higher SW48 growth inhibition (mean, $68 \pm 4 \%$ ) than that produced by $\mathrm{NaB}$ (mean, $47 \pm 3 \%$ ) or PSI-2 (mean, $49 \pm 4 \%$ ). The differences in the SW48 growth inhibition produced by combined treatment and single treatment with $\mathrm{NaB}(\mathrm{P}=0.381)$ and PSI-2 $(\mathrm{P}=0.416)$ were statistically non-significant (Fig. 5). Similar results were obtained when SW48 cells were treated with $\mathrm{NaB}$ and PSI-2 (mean, $73 \pm 4 \%$ ), NaB (mean, $58 \pm 3 \%$ ), or PSI-2 (mean, $54 \pm 5 \%$ ) for $72 \mathrm{~h}$ (Fig. 5). The differences in SW48 growth inhibition produced by combined treatment and $\mathrm{NaB}(\mathrm{P}=0.525)$ or PSI-2 $(\mathrm{P}=0.434)$ were statistically non-significant.

Human colorectal cancer cells SW1116 were not affected by exposure to NaB, PSI-2, or their combination for $24 \mathrm{~h}$ (Fig. 5). The combination of $\mathrm{NaB}$ and PSI-2 produced a marked growth inhibition of SW1116 cells after $72 \mathrm{~h}$ of treatment (mean, $77 \pm 3 \%$ ) that was comparable to the growth inhibition produced by single treatment with $\mathrm{NaB}$ (mean, $73 \pm 2 \%$ ). The combined treatment produced higher but statistically non-significant growth inhibition of SW1116 than that

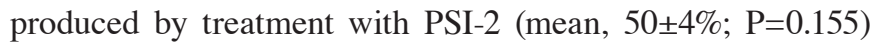
(Fig. 5). The growth of SW1116 cells was markedly inhibited when the cells were exposed for $120 \mathrm{~h}$ to the combination of $\mathrm{NaB}$ and PSI-2 (mean, $89 \pm 2 \%$ ) or $\mathrm{NaB}$ (mean, $88 \pm 13 \%$ ). Exposure of SW1116 cells to PSI-2 for $120 \mathrm{~h}$ inhibited their growth (mean, $55 \pm 5 \%$ ). Although the combination of $\mathrm{NaB}$ and PSI-2 markedly inhibited the growth of SW1116, as compared to single treatment with PSI-2, the difference in growth inhibition was statistically non-significant $(\mathrm{P}=0.083)$.

Treatment of SW837 cells with NaB, PSI-2 or their combination for $24 \mathrm{~h}$ exerted very little effect $(2-12 \%)$ on their growth (Fig. 5). However, after 72 h, single treatment with $\mathrm{NaB}$ and the combination of $\mathrm{NaB}$ and PSI-2 produced a marked comparable growth inhibition of $84 \pm 2$ and $85 \pm 2 \%$, respectively, of the SW837 cells (Fig. 5). Moreover, exposure of SW837 cells to PSI-2 for $72 \mathrm{~h}$ produced much lower growth inhibition (mean, $42 \pm 4 \%$ ) than that produced by $\mathrm{NaB}$ $(\mathrm{P}=0.029)$ or the combination of $\mathrm{NaB}$ and PSI-2 $(\mathrm{P}=0.026)$. Exposure of SW837 cells to NaB, PSI-2, or their combination for $120 \mathrm{~h}$ produced a similar growth inhibition to that observed when these cells were treated for $72 \mathrm{~h}$. NaB and the combination of $\mathrm{NaB}$ and PSI-2 produced growth inhibition of $87 \pm 2$ and $89 \pm 2 \%$, respectively (Fig. 5). Meanwhile, single treatment with PSI-2 produced a growth inhibition of $47 \pm 5 \%$ after $120 \mathrm{~h}$ of treatment. The differences in SW837 growth inhibition produced by PSI- 2 and $\mathrm{NaB}$ or the combination of 
$\mathrm{NaB}$ and PSI-2 were statistically significant, as indicated from P-values of 0.041 and 0.031 , respectively.

Augmentation of the antimitogenic effect of epoxomicin by combination with $\mathrm{NaB}$. Treatment of SW48 cells with the combination of $\mathrm{NaB}$ and the proteasome inhibitor epoxomicin produced a higher growth inhibition (mean, 37 $\pm 8 \%$ ) than that produced by $\mathrm{NaB}$ (mean, $27 \pm 2 \% ; \mathrm{P}=0.542$ ) or epoxomicin (mean, $17 \pm 3 \%$; $\mathrm{P}=0.134$ ) after $24 \mathrm{~h}$ of treatment (Fig. 6). However, the differences in growth inhibition were statistically non-significant (Fig. 6). After $72 \mathrm{~h}$ of treatment, the combination of $\mathrm{NaB}$ and epoxomicin produced a marked growth inhibition (mean, $95 \pm 8 \%$ ), as compared to single treatment with $\mathrm{NaB}$ (mean, $48 \pm 3 \%$ ) and epoxomicin (mean, $60 \pm 2 \%$ ). The differences in SW48 growth inhibition produced by combined treatment with $\mathrm{NaB}$ and epoxomicin and that produced by single treatment with $\mathrm{NaB}(\mathrm{P}=0.001)$ and epoxomicin $(\mathrm{P}=0.014)$ were statistically significant. Similar results were obtained when SW48 cells were treated for $120 \mathrm{~h}$ with the combination of $\mathrm{NaB}$ and epoxomicin (mean, $94 \pm 6 \%$ ), as compared to single treatment with $\mathrm{NaB}$ (mean, $58 \pm 3 \%$ ) and epoxomicin (mean, $64 \pm 2 \%$ ). The differences in SW48 growth inhibition produced by combined treatment and single treatment with $\mathrm{NaB}(\mathrm{P}=0.01)$ and epoxomicin $(\mathrm{P}=0.027)$ were statistically significant.

The growth of SW1116 cells was slightly affected after $24 \mathrm{~h}$ of treatment with epoxomicin (mean, 13\%) or the combination of $\mathrm{NaB}$ and epoxomicin (mean, 12.75\%). Meanwhile, $\mathrm{NaB}$ exhibited no effect on SW1116 proliferation (Fig. 6). Marked SW1116 growth inhibition was observed after $72 \mathrm{~h}$ of treatment with the combination of $\mathrm{NaB}$ and epoxomicin (mean, 96 $\pm 5 \%$ ). The differences in the growth inhibition produced by combined treatment and single treatment with $\mathrm{NaB}$ (mean, $73 \pm 2 \% ; \mathrm{P}=0.05$ ) or epoxomicin (mean, $31 \pm 5 \%$; $\mathrm{P}=0.001)$ were statistically very significant. The combination of $\mathrm{NaB}$ and epoxomicin produced a slightly higher SW1116 growth inhibition than that produced by $\mathrm{NaB}$ alone (mean, $88 \pm 14 \%$ ). However, the growth inhibition of SW1116 produced either by the combination of $\mathrm{NaB}$ and epoxomicin or $\mathrm{NaB}$ alone was much greater than that produced by epoxomicin alone (mean, $34 \pm 3 \%$ ) after $120 \mathrm{~h}$ of treatment. The differences in the growth inhibition produced by either the combination or $\mathrm{NaB}$ and that produced by epoxomicin were statistically very significant $(\mathrm{P}=0.001)$.

The combined treatment with $\mathrm{NaB}$ and epoxomicin produced a higher growth inhibition of SW837 cells (mean, $30 \pm 1.2 \%$ ) than that produced by $\mathrm{NaB}$ (mean, $12 \pm 0.6 \%$ ) and epoxomicin (mean, 17.5 $\pm 7 \%$ ) alone after $24 \mathrm{~h}$ of treatment. The difference in growth inhibition produced by combined treatment was statistically significant $(\mathrm{P}=0.05)$, as compared to that produced by $\mathrm{NaB}$ alone. However, this difference was statistically non-significant $(\mathrm{P}=0.177)$, as compared to that produced by epoxomicin alone (Fig. 6). After $72 \mathrm{~h}$, the combined treatment produced a much higher growth inhibition of SW837 (mean, 98 $\pm 3 \%$ ) than that produced by single treatment with epoxomicin (mean, $21 \pm 2 \% ; \mathrm{P}=0.001$ ). Although the combined treatment produced a higher growth inhibition than that produced by $\mathrm{NaB}$ alone (mean, $84 \pm 2 \%$ ), the difference in growth inhibition was statistically non-significant $(\mathrm{P}=0.177)$. Similar results were obtained after $120 \mathrm{~h}$ of treatment; the growth of SW837 was markedly suppressed after treatment with the combination of $\mathrm{NaB}$ and epoxomicin (mean, $99.0 \pm 1 \%$ ), as compared to that produced by epoxomicin alone (mean, 19 $\pm 2 \% ; \mathrm{P}=0.001$ ). The combined treatment produced a higher growth inhibition than that produced by $\mathrm{NaB}$ alone (mean, $87 \pm 2 \%$ ). However, the difference in growth inhibition was statistically non-significant $(\mathrm{P}=0.194)$.

Analysis of the combined effects of proteasome inhibitors and $\mathrm{NaB}$ on human colorectal cancer cells. The effects produced by treating human colorectal cancer cells SW48, SW1116 and SW837 with various combinations of $\mathrm{NaB}$ and the proteasome inhibitors (MG115, MG132, PSI-1, PSI-2 and epoxomicin) were observed as previously described $(22,23)$. The results of three independent experiments are summarized in Table I.

Various combinations of NaB and MG115 $(6.25 \mathrm{mM} / 1.0 \mu \mathrm{M}$ and $12.5 \mathrm{mM} / 2.0 \mu \mathrm{M}$ ) had additive or synergistic anti-proliferative effects on SW48 and SW1116 after 72 and $120 \mathrm{~h}$ of treatment. All the tested combinations exhibited additive or synergistic anti-proliferative effects on SW837 after $120 \mathrm{~h}$ of treatment (Table I).

Various combinations of $\mathrm{NaB}$ and MG132 (3.125 mM/0.5 $\mu \mathrm{M}, 6.25 \mathrm{mM} / 1.0 \mu \mathrm{M}$ and $12.5 \mathrm{mM} / 2.0 \mu \mathrm{M}$ ) exhibited synergistic or additive antiproliferative effects on the SW48, SW1116 and SW837 cells after $120 \mathrm{~h}$ of treatment. Additionally, these combinations had additive antiproliferative effects on SW837 after $72 \mathrm{~h}$ of treatment. The combinations of $\mathrm{NaB}$ and MG132 $(6.25 \mathrm{mM} / 1.0 \mu \mathrm{M}$ and $12.5 \mathrm{mM} / 2.0 \mu \mathrm{M})$ had additive antiproliferative effects on SW48 and SW1116 after $72 \mathrm{~h}$ of treatment.

All the tested combinations of NaB and PSI-1 exhibited additive or synergistic antimitogenic effects on the human colorectal cancer cells after 72 and $120 \mathrm{~h}$ of treatment (Table I). All of the tested combinations of $\mathrm{NaB}$ and PSI-2 except $1.56 \mathrm{mM} \mathrm{NaB}$ and $0.375 \mu \mathrm{M}$ PSI-2 produced additive or synergistic antimitogenic effects on SW48, SW1116 and SW837 after $120 \mathrm{~h}$ of treatment (Table I). The same combinations had an additive antiproliferative effect on SW837 after $72 \mathrm{~h}$ of treatment. All of the combinations of $\mathrm{NaB}$ and epoxomicin exhibited synergistic or additive antiproliferative effects on SW48, SW1116 and SW837 after 72 and $120 \mathrm{~h}$ of treatment (Table I).

These results indicate that the combinations of $\mathrm{NaB}$ and the tested proteasome inhibitors can be ranked with respect to their antimitogenic effects in the following order: $\mathrm{NaB}+$ epoxomicin $>\mathrm{NaB}+$ PSI- $1>\mathrm{NaB}+\mathrm{PSI}-2 \equiv \mathrm{Na}+\mathrm{MG} 115$ $\equiv \mathrm{NaB}+\mathrm{MG132}$. The antiproliferative activities and the type of combined treatment were time-, dose- and cell linedependent.

Cell cycle phase distribution of human colorectal cancer cells treated with NaB, proteasome inhibitors, and their combinations. FACS analysis showed that treatment of the human colorectal cancer cells with $3 \mathrm{mM} \mathrm{NaB}$ resulted in the accumulation of cells in the $\mathrm{G}_{1}$ phase $(82.7 \%)$ with a corresponding decrease in the number of cells in $\mathrm{G}_{2} / \mathrm{M}(2.61 \%)$ and $\mathrm{S}(14.7 \%)$ phases (Fig. 7). Meanwhile, treatment with $1.0 \mu \mathrm{M}$ MG115, 1.0 $\mu \mathrm{M}$ MG132, $0.1 \mu \mathrm{M}$ PSI-1, $1.5 \mu \mathrm{M}$ PSI-2, or $12 \mathrm{nM}$ epoxomicin resulted in the accumulation of cells in the S phase (55.5, 33.7, 41.5, 42.7 and $32 \%$, respectively) and the 
Table I. Analysis of the combined effects of proteasome inhibitors and sodium butyrate on human colorectal cancer cell lines.

Combined interaction of proteasome inhibitors and $\mathrm{NaB}$

in human colorectal cancer cell lines:

SW48

Single and combined treatment of

$\mathrm{NaB}$ and proteasome inhibitors

$1.56 \mathrm{mM} \mathrm{NaB}+0.25 \mu \mathrm{M} \mathrm{MG} 115$

$3.125 \mathrm{mM} \mathrm{NaB}+0.5 \mu \mathrm{M}$ MG115

$6.25 \mathrm{mM} \mathrm{NaB}+1.00 \mu \mathrm{M}$ MG115

$12.5 \mathrm{mM} \mathrm{NaB}+2.00 \mu \mathrm{M}$ MG115

$1.56 \mathrm{mM} \mathrm{NaB}+0.25 \mu \mathrm{M} \mathrm{MG} 132$

$3.125 \mathrm{mM} \mathrm{NaB}+0.5 \mu \mathrm{M}$ MG132

$6.25 \mathrm{mM} \mathrm{NaB}+1.00 \mu \mathrm{M} \mathrm{MG} 132$

$12.5 \mathrm{mM} \mathrm{NaB}+2.00 \mu \mathrm{M}$ MG132

$1.56 \mathrm{mM} \mathrm{NaB}+0.013 \mu \mathrm{M}$ PSI-1

$3.125 \mathrm{mM} \mathrm{NaB}+0.025 \mu \mathrm{M}$ PSI-1

$6.25 \mathrm{mM} \mathrm{NaB}+0.05 \mu \mathrm{M}$ PSI-1

12.5mM NaB $+0.10 \mu \mathrm{M}$ PSI- 1

$1.56 \mathrm{mM} \mathrm{NaB}+0.375 \mu \mathrm{M}$ PSI-2

$3.125 \mathrm{mM} \mathrm{NaB}+0.750 \mu \mathrm{M}$ PSI-2

$6.25 \mathrm{mM} \mathrm{NaB}+1.500 \mu \mathrm{M}$ PSI-2

$12.5 \mathrm{mM} \mathrm{NaB}+3.000 \mu \mathrm{M}$ PSI-2

$1.56 \mathrm{mM} \mathrm{NaB}+3.000 \mathrm{nM}$ Epox

$3.125 \mathrm{mM} \mathrm{NaB}+6.000 \mathrm{nM}$ Epox

$6.25 \mathrm{mM} \mathrm{NaB}+9.000 \mathrm{nM}$ Epox

$12.5 \mathrm{mM} \mathrm{NaB}+12.000 \mathrm{nM}$ Epox

SW1116

SW837

\begin{tabular}{|c|c|c|c|c|c|c|c|c|}
\hline $1 \mathrm{~d}$ & $3 \mathrm{~d}$ & $5 \mathrm{~d}$ & $1 \mathrm{~d}$ & $3 \mathrm{~d}$ & $5 \mathrm{~d}$ & $1 \mathrm{~d}$ & $3 \mathrm{~d}$ & $5 \mathrm{~d}$ \\
\hline ant & ant & ant & ant & ant & ant & ant & ant & add \\
\hline ant & ant & ant & ant & ant & ant & ant & ant & syn \\
\hline ant & add & syn & ant & syn & syn & ant & add & syn \\
\hline ant & add & add & ant & add & syn & ant & add & add \\
\hline ant & ant & ant & ant & ant & ant & ant & ant & ant \\
\hline ant & ant & syn & ant & ant & add & ant & add & syn \\
\hline ant & add & add & ant & add & add & ant & add & add \\
\hline add & add & syn & ant & add & add & ant & add & add \\
\hline ant & add & syn & ant & add & syn & ant & syn & syn \\
\hline ant & syn & syn & ant & syn & add & ant & add & syn \\
\hline ant & add & add & ant & add & add & ant & add & add \\
\hline ant & add & add & ant & add & add & ant & add & add \\
\hline ant & ant & ant & ant & ant & ant & ant & ant & ant \\
\hline ant & ant & add & ant & ant & add & ant & add & syn \\
\hline ant & add & add & ant & add & add & ant & add & add \\
\hline ant & add & add & ant & add & add & ant & add & add \\
\hline ant & syn & syn & ant & syn & syn & ant & syn & syn \\
\hline ant & syn & syn & ant & syn & syn & ant & syn & syn \\
\hline ant & syn & add & ant & syn & add & ant & syn & syn \\
\hline ant & add & add & ant & add & add & ant & add & add \\
\hline
\end{tabular}

Data are based on 3 independent experiments. ant, antagonistic; add, additive; syn, synergistic. d, day.

$\mathrm{G}_{2}$ phase (15.2, 36, 44.3, 29.9 and $45.7 \%$, respectively) with a corresponding decrease in the number of cells in the $G_{1}$ phase (29.0, 29.7, 14.1, 27.4 and 22.3\%, respectively).

Treatment of the human colorectal cancer cells with the combination of $3 \mathrm{mM} \mathrm{NaB}$ and $1.0 \mu \mathrm{M} \mathrm{MG115}$ or MG132 resulted in the accumulation of cells in the $\mathrm{G}_{1}$ phase (79.8 or $75.5 \%$, respectively) and the $G_{2}$ phase (6.73 or $14.4 \%$, respectively) with a corresponding decrease in the number of cells in the S phase (13.5 or $10 \%$, respectively) (Fig. 7 ). On the other hand, the combination of $3 \mathrm{mM} \mathrm{NaB}$ and $1.0 \mu \mathrm{M}$ PSI-1, $1.5 \mu \mathrm{M}$ PSI-2, or $12 \mathrm{nM}$ epoxomicin resulted in the accumulation of cells in the $\mathrm{G}_{2}$ phase $(45,92.7$ or $88 \%$, respectively) with a corresponding decrease in the number of cells in the $G_{1}$ phase $(55,7.29$ or $12 \%$, respectively) and the $\mathrm{S}$ phase $(0 \%)$ (Fig. 7).

The effects of $\mathrm{NaB}$, proteasome inhibitors, and their combinations on apoptosis in human colorectal cancer cells. The agarose gel electrophoresis of DNA extracted from the untreated and treated (with $\mathrm{NaB}$, proteasome inhibitors and their combinations) human colorectal cancer cells exhibited a distinct ladder pattern, which is the hallmark of apoptosis. Our results clearly demonstrated that treatment with $\mathrm{NaB}$, the proteasome inhibitors, or their combinations induced apoptotic involution. The extent of apoptosis in the human colorectal cancer cells treated with the combination of $\mathrm{NaB}$ and the proteasome inhibitors was more pronounced, as compared to that observed in the cells treated with either $\mathrm{NaB}$ or proteasome inhibitors (Fig. 8).

To investigate the type of cell death induced by $\mathrm{NaB}$, the proteasome inhibitors, and their combinations, cells were treated with $\mathrm{AO} / \mathrm{EB}$, which allows for the identification of viable, apoptotic, and necrotic cells based on color and appearance. Staining with $\mathrm{AO} / \mathrm{EB}$ of the human colorectal cancer cells treated for $24 \mathrm{~h}$ with $3 \mathrm{mM} \mathrm{NaB}$ exhibited $\sim 50 \%$ orange-stained cells. The apoptotic effect appeared earlier in cells treated with proteasome inhibitors or the combination of $\mathrm{NaB}$ and proteasome inhibitors. In fact, 30 and $50 \%$ of apoptotic cells were observed after $8 \mathrm{~h}$ of incubation with the proteasome inhibitors and their combinations with $\mathrm{NaB}$, respectively. The maximum effect was reached at $24 \mathrm{~h}$ when 50 and $80 \%$ of cells showed signs of apoptosis with the proteasome inhibitors and the combination of $\mathrm{NaB}$ and the proteasome inhibitors (data not shown).

Effects of $\mathrm{NaB}$ and epoxomicin on the activities of caspases and on cytochrome-c release. Caspase-3, a cysteine protease, 

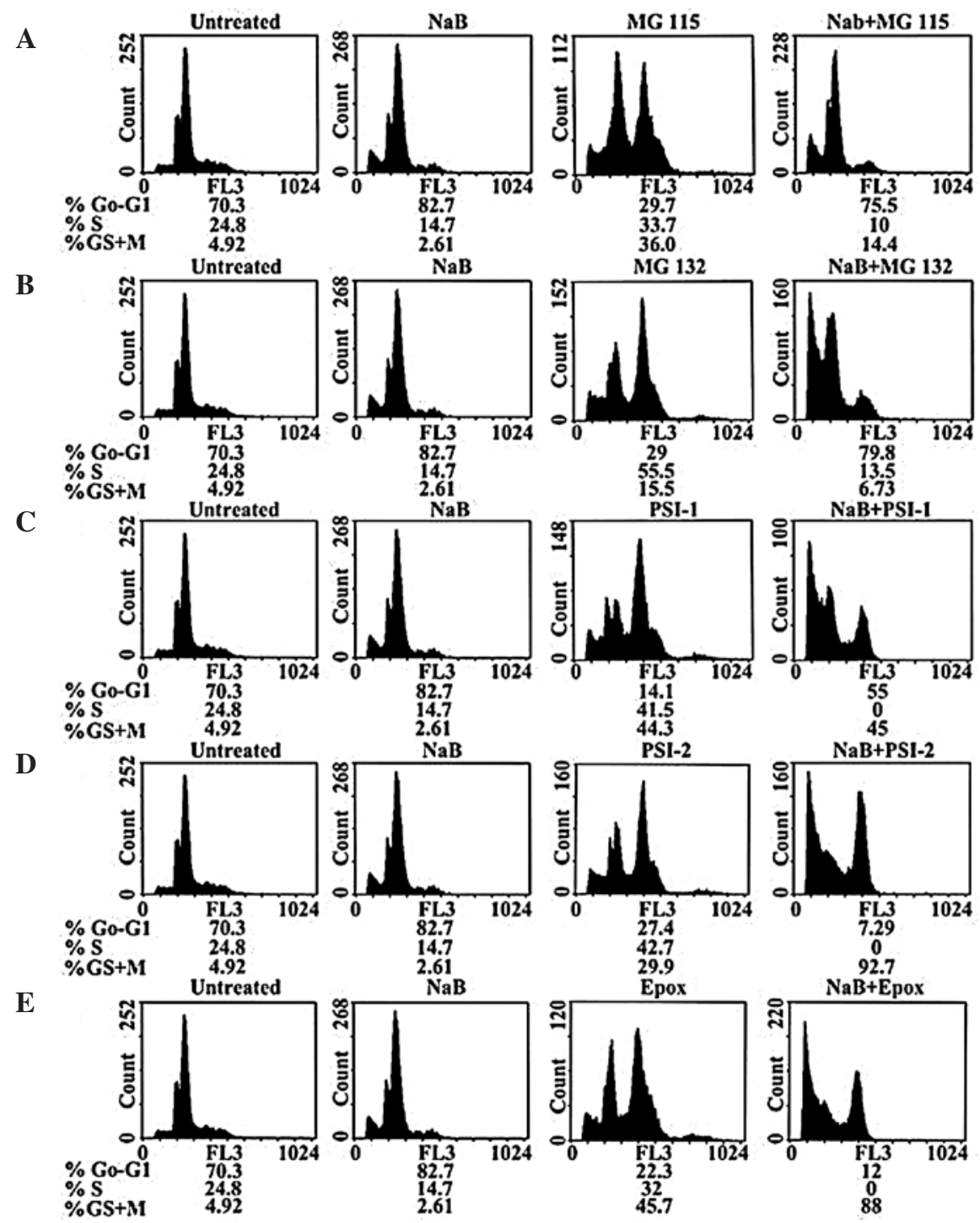

Figure 7. Cell cycle distribution of human colorectal cancer cells treated with $\mathrm{NaB}$, proteasome inhibitors and their combinations. Human colorectal cancer cells were plated $\left(5 \times 10^{5}\right.$ cells/well) into 24 -well plates and incubated at $37^{\circ} \mathrm{C}$ in a non- $\mathrm{CO}_{2}$ incubator. After $18 \mathrm{~h}$, cells were treated individually with $\mathrm{NaB}$ (3 mM), MG115 $(1.0 \mu \mathrm{M})$, MG132 $(1.0 \mu \mathrm{M})$, PSI-1 ( $0.1 \mu \mathrm{M})$, PSI-2 $(1.5 \mu \mathrm{M})$ and epoxomicin $(12 \mathrm{nM})$ or treated with the combinations NaB/MG115 $(3 \mathrm{mM} / 1.0 \mu \mathrm{M}), \mathrm{NaB} / \mathrm{MG} 132(3 \mathrm{mM} / 1.0 \mu \mathrm{M}), \mathrm{NaB} / \mathrm{PSI}-1$ (3 mM/0.1 $\mu \mathrm{M}), \mathrm{NaB} / \mathrm{PSI}-2(3 \mathrm{mM} / 1.5 \mu \mathrm{M})$ and NaB/epoxomicin $(3 \mathrm{mM} / 12 \mathrm{nM})$ for $72 \mathrm{~h}$. At least duplicate samples were analyzed and 20,000 events were scored for each sample. The vertical axis represents the relative number of events and the horizontal axis represents the fluorescence intensity. The percentage of cells in different cell cycle phases was calculated using Phoenix statistical software package.

is present in cells as an inactive pro-enzyme. Activation of this form requires cleavage at specific aspartate sites to produce subunits of $\mathrm{M}_{\mathrm{r}} 17,000 \mathrm{Da}$ and $\mathrm{M}_{\mathrm{r}} 12,000 \mathrm{Da}$. The active enzyme takes part in the execution phase of apoptosis (26).

In this study, $\mathrm{NaB}$ induced the activation of caspase-3 in human colorectal cancer cells. The direct estimation of caspase-3 activity showed a 3 -fold increase after exposure to $3 \mathrm{mM} \mathrm{NaB}$. The effect was inhibited by both z-VAD-fmk and Ac-DEVD (Fig. 9A). Exposure of colorectal cancer cells to epoxomicin enhanced the activity of caspase-3, and z-VAD-fmk $(100 \mu \mathrm{M})$ was capable of suppressing the effect exerted by epoxomicin on caspase activity (Fig. 9A).

The activation of caspase- 3 was also shown by means of Western blot analysis using a primary antibody that recognizes both the $\mathrm{M}_{\mathrm{r}} 32,000 \mathrm{Da}$ pro-enzyme and the $\mathrm{M}_{\mathrm{r}} 12,000 \mathrm{Da}$ subunit of the active enzyme. As shown in Fig. 9B, in the cells treated with $3 \mathrm{mM} \mathrm{NaB}$, the p12 subunit increased, whereas that of the pro-enzyme diminished at the same time. The addition of z-VAD-fmk suppressed the production of the p12 subunit induced by $\mathrm{NaB}$, providing evidence that the activation of caspase-3 was stimulated by caspase activities inhibited by z-VAD-fmk (Fig. 9B).

To demonstrate the proteolytic activity of caspase in cells treated with $\mathrm{NaB}$, we studied the fragmentation of two nuclear proteins, PARP and lamin $\mathrm{B}$, which are cleaved by caspase activities (27). PARP is a protein of $\mathrm{M}_{\mathrm{r}} 16,000 \mathrm{Da}$ that is associated with chromatin and is cleaved in a number of cell death systems by cysteine proteases to yield two fragments of $\mathrm{M}_{\mathrm{r}}$ 24,000 Da. Western blot analysis revealed that treatment of the human colorectal cancer cells with $3 \mathrm{mM}$ $\mathrm{NaB}$ induced the proteolytic cleavage of the $\mathrm{M}_{\mathrm{r}} 116$, Da PARP protein to yield the characteristic $M_{r} 85,000$ Da 
A

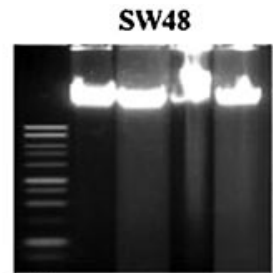

\section{$\mathrm{NaB} 3 \mathrm{mM}$}

B
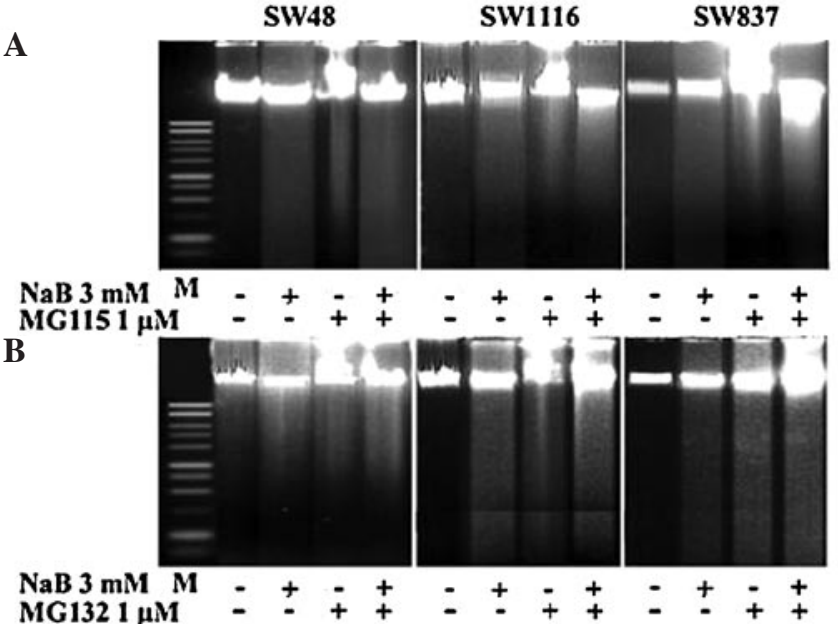

C
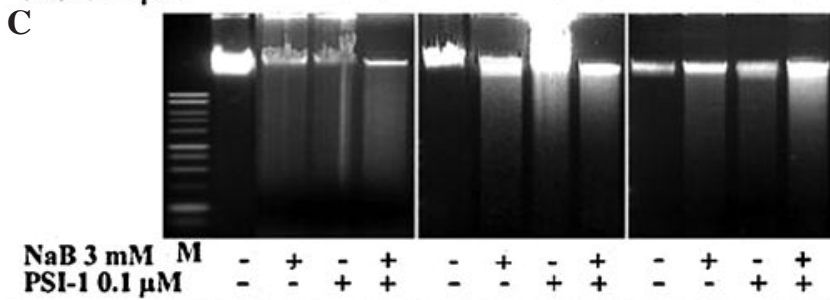

D
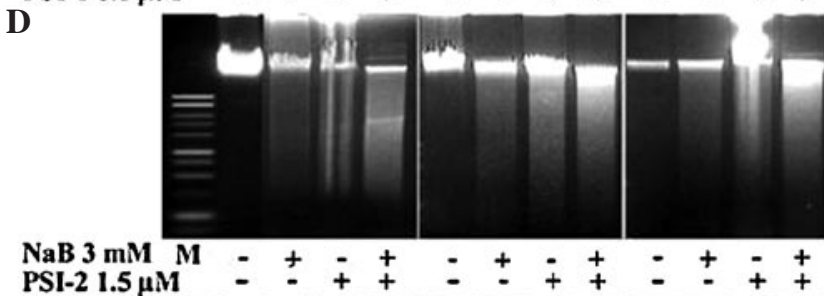

$\mathbf{E}$

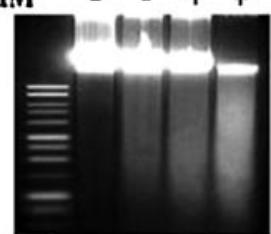

$\mathrm{NaB} 3 \mathrm{mM}$
Epox $12 \mathrm{nM}$
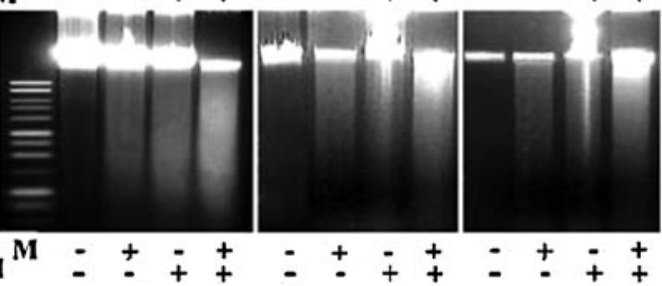

Figure 8. Assessment of apoptosis in human colorectal cancer cells treated with $\mathrm{NaB}$, proteasome inhibitors and their combinations. Human colorectal cancer cells were plated $\left(5 \times 10^{5}\right.$ cells/well) into 24 -well plates and incubated at $37^{\circ} \mathrm{C}$ in a non- $\mathrm{CO}_{2}$ incubator. After $18 \mathrm{~h}$, cells were treated individually with $\mathrm{NaB}(3 \mathrm{mM})$, MG115 $(1.0 \mu \mathrm{M})$, MG132 $(1.0 \mu \mathrm{M})$, PSI-1 $(0.1 \mu \mathrm{M})$, PSI-2 $(1.5 \mu \mathrm{M})$ and epoxomicin $(12 \mathrm{nM})$ or treated with the combinations NaB/MG115 (3 mM/1.0 $\mu \mathrm{M}), \mathrm{NaB} / \mathrm{MG} 132(3.0 \mathrm{mM} / 1.0 \mu \mathrm{M})$, $\mathrm{NaB} / \mathrm{PSI}-1(3.0 \mathrm{mM} / 0.1 \mu \mathrm{M}), \mathrm{NaB} / \mathrm{PSI}-2(1.5 \mu \mathrm{M})$ and NaB/epoxomicin $(3.0 \mathrm{mM} / 12.0 \mathrm{nM})$ for $72 \mathrm{~h}$. DNA fragments were extracted and analyzed on $1 \%$ agrose gel.

fragment (Fig. 9B). Additionally, $\mathrm{NaB}(3.0 \mathrm{mM})$ induced the cleavage of lamin $B$. The effects on both the cleavage of PARP and lamin B were suppressed by the addition of z-VAD-fmk (Fig. 9B). Similar results were obtained when human colorectal cancer cells were treated with epoxomicin $(12.0 \mathrm{nM})$ and the combination of $\mathrm{NaB}(3 \mathrm{mM})$ and epoxomicin (12.0 nM) (data not shown).

Mitochondria play a decisive role in apoptosis (27), functioning as integrators of different pro-apoptotic signaling pathways. In response to these signals, mitochondria activate mega-channels (also called permeability transition pores) that are present between the inner and outer mitochondrial membranes. BcL2, a fundamental death antagonist protein, inhibits mega-channel opening, whereas Bax, a death antagonist protein, facilitates the opening of mega-channels (28). The increase in the content of agonists and the concomitant decrease in the content of antagonists stimulate the release of cytochrome- $c$ from the mitochondria, with the consequent activation of caspase activities. As shown in Fig. 9C, treatment with $3 \mathrm{mM} \mathrm{NaB}, 12 \mathrm{nM}$ epoxomicin, and their combination for $72 \mathrm{~h}$ seemed to favor the release of cytochrome- $c$ from the mitochondria as the mitochondrial level of cytochrome- $c$ appeared diminished and the cytosolic level increased.

Differential expression of p53, p21 Wafl, p27 ${ }^{\mathrm{Kipl}}$, Bax and BcL2 proteins in human colorectal cancer cells treated with $\mathrm{NaB}$, proteasome inhibitors and the combinations of $\mathrm{NaB}$ and proteasome inhibitors. Western blot analysis (Fig. 10A and B) revealed that treatment of the human colorectal cancer cells with $\mathrm{NaB}$ or proteasome inhibitors differentially decreased the levels of BcL2 and concomitantly increased the levels of Bax. Moreover, the combinations of $\mathrm{NaB}$ with each of the tested proteasome inhibitors modified the suppressive effects of $\mathrm{NaB}$ and proteasome inhibitors on BcL2 levels and enhanced the enhancing effect on Bax levels (Fig. 10A and B).

Studies from several laboratories have suggested that deregulation of cell progression may be involved in the initiation of apoptosis (29). In addition, it has been reported that the ubiquitin-proteasome pathway plays an essential role in the regulation of several important cell cycle proteins, including p53 (30) and the cyclin-dependent kinase inhibitors $\mathrm{p} 21^{\text {Waf1 }}$ (31) and p27 Kip1 (32).

After treatment with $\mathrm{NaB}$, proteasome inhibitors (MG115, MG132, PSI-1, PSI-2 and epoxomicin), and their combinations, the protein levels of $\mathrm{p} 53$, p2 $1^{\text {Waf } 1}$ and $\mathrm{p} 27^{\mathrm{Kip} 1}$ were examined by Western blotting. It is well known that ubiquitin-proteasome systems play an important role in the degradation of many short-lived proteins, including p53 (33). As shown in Fig. 10C and $\mathrm{D}$, treatment of the human colorectal cancer cells with $3.0 \mathrm{mM} \mathrm{NaB}$ lowered the level of p53 by $\sim 50 \%$ with respect to the control. Since p53 is cleaved by the ubiquitin-proteasome complex, the inhibition of this activity would be expected to stabilize the p53 protein. To investigate this possibility, the effect of proteasome inhibitors MG115, MG132, PSI-1, PSI-2 and epoxomicin on the p53 level was determined. Clear differential enhancement in the levels of p53 was observed after $72 \mathrm{~h}$ exposure to $1.0 \mu \mathrm{M}$ MG115, 1.0 $\mu \mathrm{M}$ MG132, 1.0 $\mu \mathrm{M}$ PSI-1, $1.5 \mu \mathrm{M}$ PSI-2 or $12.0 \mathrm{nM}$ epoxomicin (Fig. 10C and D).

Notably, when human colorectal cancer cells were treated with the combinations of each of these proteasome inhibitors and $\mathrm{NaB}$, the proteasome inhibitors counteracted the decreasing effects of $\mathrm{NaB}$ on $\mathrm{p} 53$. In this way, in the colorectal cancer cells exposed for $72 \mathrm{~h}$ to combined treatment, the levels of p53 were higher than those in the control and were comparable to the levels found in the cells treated with the proteasome inhibitors alone (Fig. 10C and D).

It is well known that $\mathrm{p} 21^{\text {Waf1 }}$, a transcriptional target of $\mathrm{p} 53$, plays a role in the control of the cell cycle. Moreover, it has been reported that $\mathrm{NaB}$ is capable of stimulating $\mathrm{p} 21^{\text {Waf1 }}$ expression in a p53-independent manner (34). The results presented in this study showed that in the human colorectal cancer cells, $\mathrm{NaB}$ increased the level of the $\mathrm{p} 21^{\text {Waf } 1}$ protein. Treatment of cancer cells with the rest of the proteasome inhibitors and their combi- 


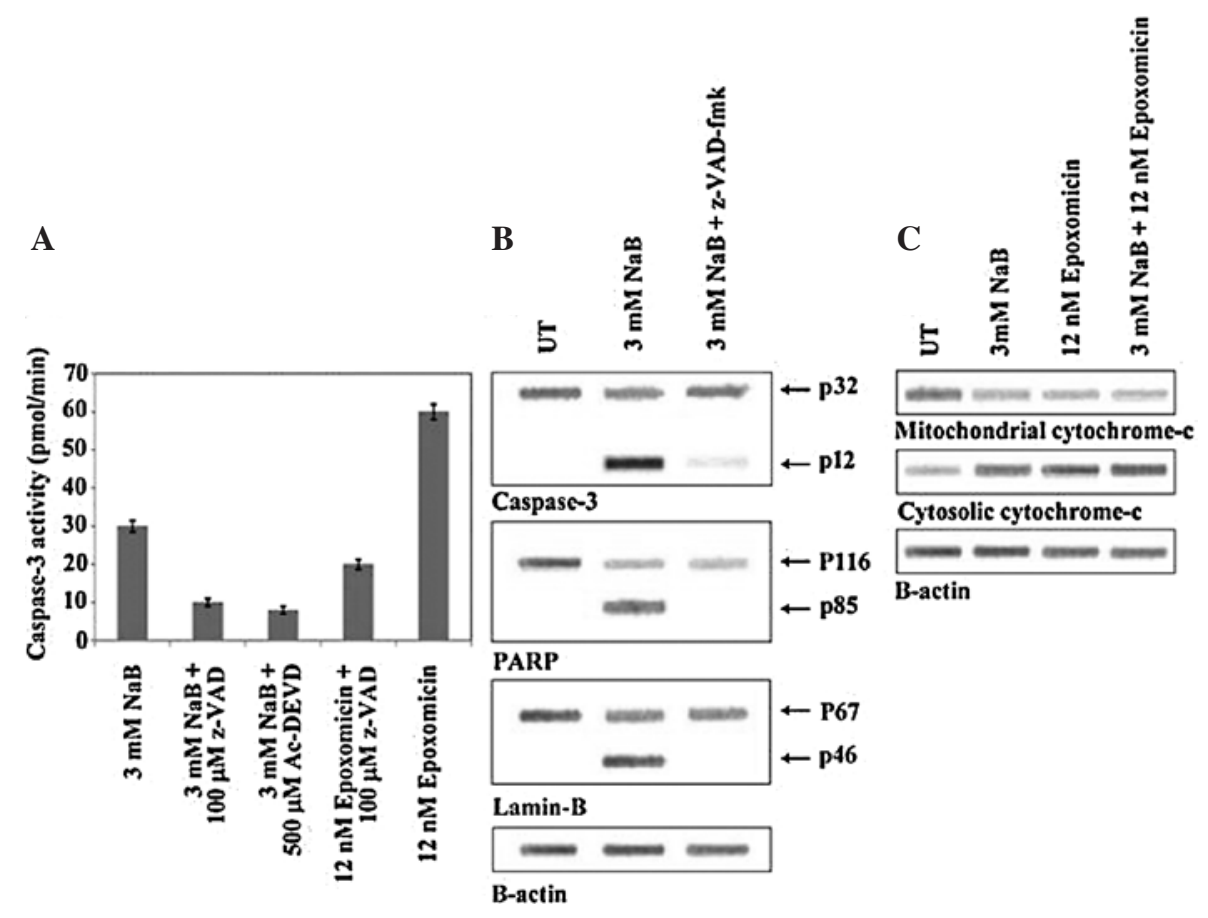

Figure 9. Analysis of caspase-3, PARP, lamin B and cytochrome- $c$ in human colorectal cancer cells treated with NaB, epoxomicin and their combination. (A) Cells were treated with $3.0 \mathrm{mM} \mathrm{NaB}$ or $12.0 \mathrm{nM}$ epoxomicin in the absence or presence of 100 or $500 \mu \mathrm{M} \mathrm{Ac-DEVD}$, and caspase- 3 activity was measured using a colorimetric assay according to the manufacturer's instructions. Values are the mean \pm SE from three separate experiments. (B) Cell lysates of human colorectal cancer cells treated with $3.0 \mathrm{mM} \mathrm{NaB}$ in the absence or presence of $100 \mu \mathrm{M} \mathrm{z}$-VAD-fmk were resolved by $10 \%$ SDS-PAGE, immunoblotted, and detected using specific antibodies as described in Materials and methods. (C) Cells were treated with $3.0 \mathrm{mM} \mathrm{NaB}, 12.0 \mathrm{nM}$ epoxomicin or their combination for $24 \mathrm{~h}$. Mitochondrial and cytosolic fractions were resolved by SDS-PAGE, proteins were immunoblotted and detected using specific antibodies.

nations with $\mathrm{NaB}$ for $72 \mathrm{~h}$ differentially increased the levels of p2 $1^{\text {Waf1 }}$ depending upon the type of proteasome inhibitor and its combination with $\mathrm{NaB}$. Similar to $\mathrm{p} 21^{\text {Waf1 }}$, treatment with $\mathrm{NaB}$, proteasome inhibitors and their combinations resulted in increased expression of p27 $7^{\mathrm{Kipl}}$ (Fig. 10C and D).

\section{Discussion}

The proteasome is a multi-catalytic protease complex that is responsible for the ubiquitin-dependent turnover of cellular proteins (35). It is estimated that over $80 \%$ of intracellular proteins are degraded by proteasomes. Besides carrying out protein turnover, the ubiquitin proteasome pathway plays an essential role in regulating protein levels during the cell cycle, during apoptosis, in response to cellular stress (i.e. DNA damage or hypoxia), and during intracellular signal transduction (36).

Clinical validation of the proteasome as a therapeutic target in oncology has been provided by the boronic acid bortezomib, a dipeptide (36). Bortezomib has proven to be effective as a single agent in multiple myeloma (37) and against some forms of non-Hodgkin's lymphoma (38); however, despite the clinical success of bortezomib, a significant fraction of patients remain refractory to treatment $(37,38)$. Furthermore, a number of side effects, including cardiotoxicity $(39,40)$, painful peripheral neuropathy (41) and thrombocytopenia (42), have restricted treatment of bortezomib to a biweekly dosing schedule that allows for the full recovery of proteasome activity between doses (43). In addition, drug resistance ultimately emerges in all tumors that initially respond to proteasome inhibitors (44).
The induction of apoptosis has been recognized as an effective tool in the therapeutic treatment of many types of tumors, and apoptosis can be triggered by a number of drugs, such as proteasome inhibitors. However, the efficacy of treatment with apoptotic drugs is limited by their toxicity and cell resistance (45). Sodium butyrate, a natural product that is capable of inducing apoptosis in a number of tumor cells, exhibits a low degree of clinical toxicity (46) and may therefore be of particular importance in tumor therapy. With this in mind, the aim of the current study was to investigate whether sodium butyrate enhances the anticancer effects of proteasome inhibitors MG115, MG132, PSI-1, PSI-2 and epoxomicin in human colorectal cancer carcinoma.

The results obtained from this study demonstrated that single treatment of human colorectal cancer cells with $\mathrm{NaB}$ and proteasome inhibitors MG115, MG132, PSI-1, PSI-2 or epoxomicin inhibited cell growth in a time- and dose-dependent manner (Fig. 1). Moreover, the combinations of proteasome inhibitors and $\mathrm{NaB}$ markedly inhibited the proliferation of the human colorectal cancer cells in a dose- and time-dependent manner (Figs. 2-6); the combinations of proteasome inhibitors and $\mathrm{NaB}$ produced additive and synergistic growth inhibitory effects (Table I). Our results are consistent with those reported by Giuliano et al who found that the treatment of retinoblastoma Y79 cells with $\mathrm{NaB}$ progressively reduced cell viability, and after $72 \mathrm{~h}$ the number of cells decreased by approximately $70 \%$ (47). Our results are also consistent with those obtained by Kim et al who demonstrated that MG132 inhibited the cellular growth of HCT116 cells in a time- and dose-dependent manner (48). Similar to those reported by Fan et al our results 
A

(a)

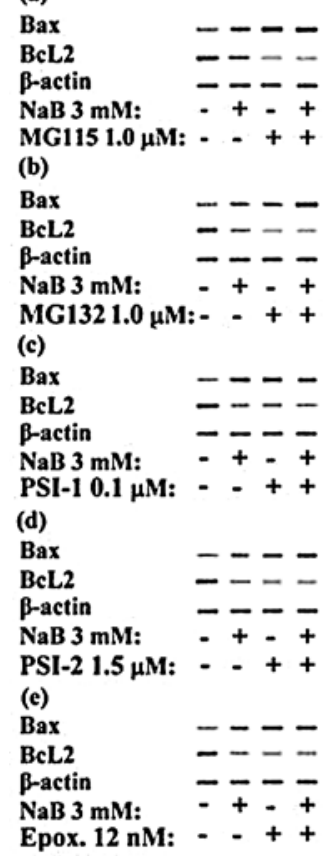

B
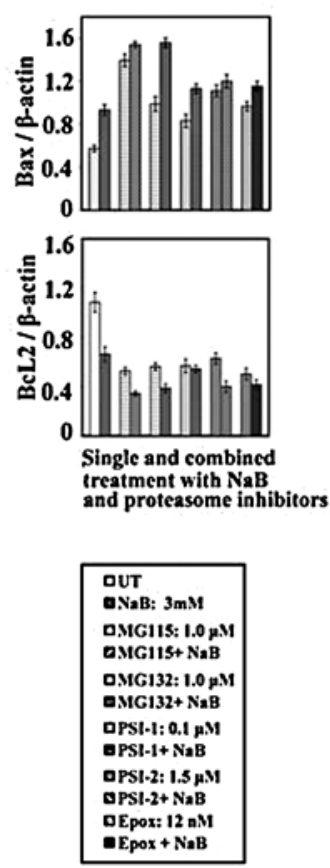

C

(a)

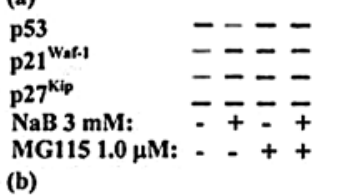

(b)

p53 $\quad---\overline{-}$

p27 $7^{\text {Kip }} \quad---\overline{-}$

NaB 3 mM: $\quad \bar{t} \overline{+}$

MG132 $1.0 \mu \mathrm{M}:-{ }^{-}+$

(c)

p53 $\quad---$

p21 War-1 $\quad---$

p27 $7^{\text {Kip }} \quad---$

NaB 3 mM: $\quad$ -

PSI-1 0.1 $\mu \mathrm{M}$ : : - + +

(d)

p53

p21 war.1 $=-\div=$

p27 ${ }^{\text {Kip }} \quad--\cdots$

$\mathrm{NaB} 3 \mathrm{mM}: \quad \overline{+}-\bar{t}$

PSI-2 $1.5 \mu \mathrm{M}$ : - - +

(e)

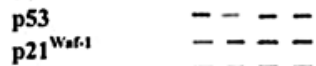

p27 ${ }^{\text {Kip }} \quad-\because-ニ$

NaB 3 mM: $\quad \overline{+} \overline{+}$
D
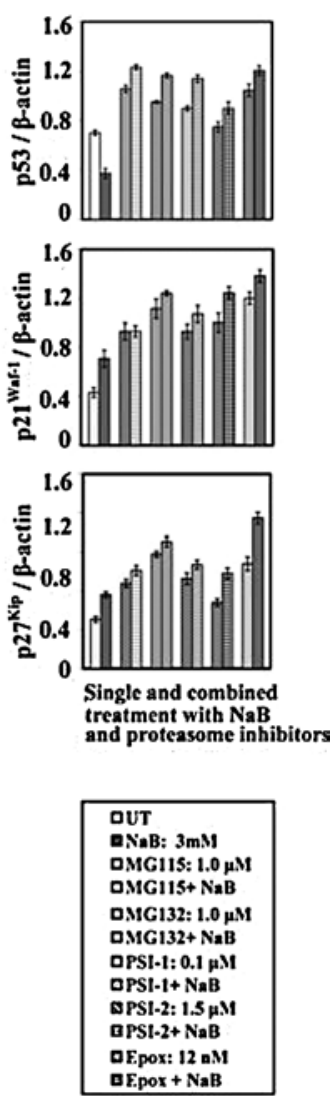

Figure 10. Expression of cell cycle and apoptosis regulatory proteins in human colorectal cancer cells treated with NaB, proteasome inhibitors and their combinations. Human colorectal cancer cells were plated $\left(1-2 \times 10^{6}\right.$ cells/well) into 24 -well plates and incubated at $37^{\circ} \mathrm{C}$ in a non- $\mathrm{CO}_{2}$ incubator. After $18 \mathrm{~h}$, cells were treated individually with $\mathrm{NaB}(3.0 \mathrm{mM})$, MG115 $(1.0 \mu \mathrm{M})$, MG132 $(1.0 \mu \mathrm{M})$, PSI-1 $(0.1 \mu \mathrm{M})$, PSI-2 $(1.5 \mu \mathrm{M})$ and epoxomicin $(12.0 \mathrm{nM})$ or treated with the combination of NaB/MG115 (3.0 mM/1.0 $\mu \mathrm{M}), \mathrm{NaB} / \mathrm{MG} 132$ (3.0 mM/1.0 $\mu \mathrm{M}), \mathrm{NaB} / \mathrm{PSI}-1$ (3.0 mM/0.1 $\mu \mathrm{M}), \mathrm{NaB} / \mathrm{PSI}-2$ (1.5 $\mu \mathrm{M})$ or NaB/epoxomicin $(3.0 \mathrm{mM} / 12.0 \mathrm{nM})$ for $72 \mathrm{~h}$. Cell extracts of untreated and NaB-, proteasome inhibitor- or the combinations of NaB and proteasome inhibitor-treated colorectal cancer cells were analyzed for the expression of Bax, Bc12, p2 $1^{\text {Wafl }}, \mathrm{p} 27^{\mathrm{Kipl}}$, p53 and $\beta$-actin by Western blot analysis. The blots (A and C) were scanned, and the intensities of the bands were determined (B and D).

showed that MG132 inhibited the growth of human colorectal cell lines in a dose- and time-dependent manner (24). Similar results were recently reported by $\mathrm{Wu}$ et al who found that MG-132 significantly suppressed the proliferation of colon cancer SW1116 and HT-29 cells (49). However, our results contradicted those obtained by Denlinger $e t a l$ who found that non-small cell lung cancer cell lines treated with $\mathrm{NaB}$ were resistant to NaB-induced apoptosis (50).

Flow cytometric analysis showed that $\mathrm{NaB}$ induced an arrest of human colorectal cancer cells at the $\mathrm{G}_{1}$-phase. Our results are similar to those reported by Abramova et al who showed that $\mathrm{NaB}$ induced $\mathrm{G}_{1}-\mathrm{S}$ arrest in rat embryo fibroblast cells that were transformed with the oncogenes E1A and c-Ha-Ras (51). On the other hand, these results contradict the observation of other investigators $(47,52)$. In the present study, the treatment of colorectal cancer cells with proteasome inhibitors resulted in the accumulation of cells in the $\mathrm{S}$ phase and $\mathrm{G}_{2}$ phase. Meanwhile, the combinations of $\mathrm{NaB}$ and MG115 or MG132 induced an arrest of the colorectal cancer cells in the $\mathrm{G}_{1}$ phase and $\mathrm{G}_{2}$ phase. Conversely, the combinations of NaB and PSI-1, PSI-2 or epoxomicin growth arrested colorectal cancer cells in the $\mathrm{G}_{2}$ phase (Fig. 7).
Coordinated proteolytic activity of the ubiquitinproteasome system has proven to be crucial to the normal progression of the cell cycle. In this study, the levels of $\mathrm{p} 21^{\text {Waf } 1}$ and $\mathrm{p} 27^{\mathrm{Kip} 1}$ were markedly increased following treatment with the combinations of $\mathrm{NaB}$ and each of the tested proteasome inhibitors (Fig. 10C and D). Other researchers have demonstrated the accumulation of $\mathrm{p} 21^{\text {Wafl }}$ and $\mathrm{p} 27^{\mathrm{Kip} 1}$ in different cell lines treated with different proteasome inhibitors $(24,53)$. Our results are also in agreement with those reported recently by Wu et al (49) who demonstrated that MG-132 activated bone morphogenetic protein (BMP) signaling, which manifested as an increase in the up-regulation of p21 Wafl and p27 ${ }^{\text {Kipl }}$ expression as well as Smad 1/5/8 phosphorylation. Knockdown of the BMP receptor II abolished Smad $1 / 5 / 8$ phosphorylation, the induction of $\mathrm{p} 21^{\text {Wafl }}$ and $\mathrm{p} 27^{\mathrm{Kip} 1}$, and the inhibition of cell proliferation that was induced by MG132. These findings suggest that proteasome inhibition suppresses gastric cancer cell proliferation via activation of BMP signaling, demonstrating a novel aspect of proteasome function in the regulation of colon cancer cell proliferation (49). Overexpression of p27 $7^{\text {Kip } 1}$, as reported in this study, can directly result in apoptosis (54). Recently, Timmerbeul et al 
demonstrated that $\mathrm{p} 27^{\mathrm{Kip} 1}$ stabilization prevents progression from adenomatous polyps to invasive intestinal cancer (55). Proteasome-induced cytotoxicity could potentially result from several events, including the stabilization and deregulated function of cyclins, CDK inhibitors, tumor suppressor proteins, and a large number of other proteins that are associated with cell cycle progression (33). Inhibiting the degradation of key cell cycle regulatory proteins causes a disparity in the proliferative signals and eventually leads to apoptosis.

In the present study, the human colorectal cancer cells exhibited a distinct ladder pattern that is indicative of apoptosis following treatment with $\mathrm{NaB}$, proteasome inhibitors, or their combinations. The extent to which apoptosis occurred in colorectal cancer cells treated with the combinations of $\mathrm{NaB}$ and the proteasome inhibitors was more pronounced than it was when produced by a single treatment with $\mathrm{NaB}$ or the proteasome inhibitors (Fig. 8). These results are consistent with those reported by other researchers $(24,47,48)$. Quite recently, similar results were obtained using a combination of the proteasome inhibitor bortezomib and thiazol antibiotics, which synergistically induced apoptosis in prostate cancer cells (56). Also, the combination of the novel proteasome inhibitor NPI-0052 and lenalidomide induced apoptosis in multiple myeloma cell lines and in multiple myeloma cells (57). Moreover, Matondo et al investigated the induction of apoptosis by proteasome inhibitors in several human myeloid leukemia (AML) cell lines and in primary cells from patients, and found that various AML subtypes may present different responses to proteasome inhibitors and that the amount of $20 \mathrm{~S}$ proteasome in AML cells may be predictive of the cellular response to these inhibitors (58).

Members of the ICE family of cysteine proteases are present as inactive zymogens within the cell and are processed at the onset of apoptosis into enzymatically active heterodimer complexes (59). Three of these caspases, including caspase-3, -6 and -7 , have been implicated in the execution phase of apoptosis (60). Caspase-3 was shown to cleave a wide range of cytoplasmic and nuclear proteins (60); caspase-7 is closely related to caspase-3 and has the same synthetic substrate specificity in vitro (61). PARP cleavage has been widely used as an indicator of the activation of caspase-3 or of closely related enzymes with similar substrate specificity (62). Similarly, caspase-7 is also involved in the cleavage of PARP during apoptosis (63). In the present study, butyrate or tested proteasome inhibitor-induced apoptosis was preceded by the activation of caspase-3, which was clearly observed at $24 \mathrm{~h}$ of treatment by direct measurement of its activity (Fig. 9A). Western blot analysis also demonstrated the conversion of procaspase-3 into the active form of the enzyme (Fig. 9B). Activation of caspase- 3 was accompanied by degradation of PARP with the production of the $\mathrm{M}_{\mathrm{r}} 85 \mathrm{kDa}$ fragment (Fig. 9B). The observation that $\mathrm{NaB}$ also provokes the degradation of lamin B, a substrate of caspase-6 (64), suggests that other caspases besides caspase- 3 could be involved in butyrate-induced apoptosis. All of these events preceded the appearance of morphological signs that were observed in a large percentage of cells after a 48-h treatment.

Members of the BcL2 gene family are major regulators of programmed cell death. BcL2 is a potent inhibitor of apoptosis, while Bax, one of the BcL2 family genes, promotes apop- tosis. Bax can dimerize with BcL2, and the regulation of the BcL2-Bax heterodimer determines whether a cell will continue to grow or undergo apoptosis (65). BcL2, located on the outer mitochondrial membrane, inhibits cytochrome- $c$ release, thereby blocking apoptosis (66); conversely, Bax induces caspase activation and apoptosis via cytochrome- $c$ release (34). The present study tested whether $\mathrm{NaB}$, epoxomicin, or their combination is capable of inducing changes in the levels of cytochrome- $c$ that is present in both the mitochondria and cytosol. The results shown in Fig. 9C showed that after $24 \mathrm{~h}$ of treatment, cytochrome- $c$ was released from the mitochondria under the influence of $\mathrm{NaB}$, epoxomicin, and their combination. Such an event could be responsible for the production of the apoptosome that, with the consequent activation of caspase-9, activates caspase-3 (67). The release of cytochrome-c was induced in the colorectal cancer by a decrease in the level of the anti-apoptotic factor BcL2 as well as concomitant enhancement in the level of the pro-apoptotic factor Bax in the human colorectal cancer cells treated with $\mathrm{NaB}$, proteasome inhibitors, and their combinations (Fig. 10A and B).

It has been ascertained that $26 \mathrm{~S}$ proteasome inhibitors are capable of triggering apoptosis in rapidly dividing cells (30); such an effect has been correlated with the ability of proteasome inhibitors to increase the intracellular levels of many short-lived factors (32). However, it has been suggested that apoptosis that is induced by proteasome inhibitors can be a consequence of the activation of c-Jun NH2-terminal kinase (68), an enzyme that is involved in the initiation of programmed cell death.

The results presented in this study clearly indicate that proteasome inhibitors MG115, MG132, PSI-1, PSI-2 and epoxomicin induced apoptosis (Fig. 8), together with a marked increase in the level of the short-lived protein p53 (Fig. 10C and D). Expression of the p53 protein is controlled largely by $\mathrm{mdm}-2 / \mathrm{hdm}-2-$ mediated ubiquitylation and is degraded via the proteasome. It therefore stands to reason that proteasome inhibitors will result in the accumulation of p53 in cells that contain the wild-type protein. Furthermore, our results demonstrated that the tested proteasome inhibitors increased the level of Bax protein (Fig. 10A and B), a factor that seems to be involved in the p53-mediated response as it favors the release of cytochrome- $c$ from the mitochondria into the cytosol and the consequent activation of caspase-3. Our results are in agreement with those reported by Williams and McConkey (69) who found that bortezomib stabilized p53 and induced its nuclear translocation in human LNCaP prostate cancer cells (69). In addition, bortezomib activated p53 downstream target genes, including p21, Fas, and Bax and transfection with the human papilloma virus E6 protein, which blocked p53, attenuated bortezomib-induced cell death (69).

The results reported in this study demonstrate that $\mathrm{NaB}$ decreases the levels of p53, most likely through the activation of the $26 S$ proteasome. Also, the finding that the tested proteasome inhibitors induced apoptosis and concomitantly increased the levels of p53 suggests a possible synergistic interaction between $\mathrm{NaB}$ and the tested proteasome inhibitors in the induction of apoptosis in human colorectal cancer cell lines. This postulate was confirmed by our results, which illustrate the synergistic relationship between $\mathrm{NaB}$ and proteasome inhibitors on apoptosis. These effects are likely a result of the 
inhibition of proteasome activity by the proteasome inhibitors with the suppression of the stimulatory action of butyrate; consequently, the cells were prevented from decreasing their levels of p53. The presence of adequate amounts of p53 most likely enhances the susceptibility of the cells to apoptosis induction. A synergistic effect was reported by Medina et al (70) who observe that cells primed with butyrate were rendered highly susceptible to apoptosis by staurosporine, an agent that causes mitochondrial release of cytochrome- $c$.

In the present study, when the colorectal cancer cells were simultaneously exposed to the proteasome inhibitors and $\mathrm{NaB}$, Bax protein levels increased markedly compared to single treatments. Bax protein is the product of a gene that represents a transcriptional target of p53. In addition, BcL2 levels in these cells were down-regulated. Our results concur with those reported in another study (71). Meanwhile, Zhu et al did not find any changes in the expression of BcL2 or Bcl-XL in human colorectal, lung and ovarian cancer cells that were treated with bortezomib (72).

The increase in the Bax levels and the concomitant decrease in the BcL2 levels could have been responsible for the enhanced release of cytochrome- $c$ from the mitochondria, with the consequent activation of caspase- 3 and the induction of apoptosis. Our results agree with Goldstein et al who show that the release of cytochrome- $c$ during apoptosis via GFA-tagged cytochrome- $c$ was rapid, complete and kinetically invariant (73). Also, our results are in agreement with those reported by Zhu et al who found that cytochrome- $c$ release was detectable in as little time as $3 \mathrm{~h}$, and that a dramatic cytochrome- $c$ release was detected at $18 \mathrm{~h}$ following bortezomib treatment (72).

The ability of butyrate to influence cell function is associated with its regulation of gene expression, which is often attributed to its inhibition of histone deacetylase (74). This results in the hyperacetylation of histones and the enhancement of the accessibility of transcription factors to nucleosomal DNA (75). However, it is likely that butyrate has other intracellular targets, including hyperacetylation of nonhistone proteins, alteration of DNA methylation, selective inhibition of histone phosphorylation, and modulation of intracellular kinase signaling (74). This multiplicity of effects may underlie the ability of butyrate to modulate gene expression and impact the key regulators of apoptosis and the cell cycle.

We therefore conclude that the synergistic interactions between $\mathrm{NaB}$ and proteasome inhibitors MG115, MG132, PSI-1, PSI-2, or epoxomicin are closely correlated with the increased levels of the pro-apoptotic factor p53 and subsequent p2 $1^{\text {Wafl }}$ transactivation, resulting in cell cycle arrest. Increases in p53 activity also results in the up-regulation of Bax and induced apoptosis. Combined treatment with $\mathrm{NaB}$ and proteasome inhibitors may also directly induce the up-regulation of both Bax and $\mathrm{p} 27^{\mathrm{Kipl}}$; accumulation of $\mathrm{p} 27^{\mathrm{Kip} 1}$ contributes to both apoptosis and cell cycle arrest.

The synergistic apoptotic effects of $\mathrm{NaB}$ and proteasome inhibitors may open new and interesting perspectives in the therapeutic strategy for the treatment of human colorectal cancer. It is of interest that the proteasome inhibitors seem to behave as apoptotic agents only in rapidly dividing cells while protecting quiescent cells from apoptosis that may be triggered by many different compounds (30). Due to this particular behavior, proteasome inhibitors may represent a new alternative in the treatment of certain proliferative diseases. In addition, the association between a proteasome inhibitor and other effective agents of apoptosis could induce a clear effect at lower concentrations of the compounds, as is shown in this study, thereby reducing the toxicity of the therapeutic treatment.

\section{Acknowledgements}

This study was supported by Kuwait University, Research grant no. SL04/02. The author gratefully acknowledge the help of Dr Rajaa Al-Attiyah and Mrs. Amany El-Shazely of the Department of Microbiology, Faculty of Medicine, University of Kuwait who performed the flow cytometric analysis.

\section{References}

1. Mani A and Gelmann EP: The ubiquitin-proteasome pathway and its role in cancer. J Clin Oncol 23: 4776-4789, 2005.

2. Bowerman B and Kurz T: Degrade to create: developmental requirements for ubiquitin-mediated proteolysis during early C. elegans embryogenesis. Development 133: 773-784, 2006.

3. Naujokat C and Hoffmann S: Role and function of the $20 \mathrm{~S}$ proteasome in proliferation and apoptosis. Lab Invest 82: 965-980, 2002.

4. Collins GA and Transey WP: The proteasome: a utility for transcription. Current Opin Genet Dev 16: 197-202, 2006.

5. Tylor $\mathrm{C}$ and Jobin $\mathrm{C}$ : Ubiquitin protein modification and signal transduction: Implications for inflammatory bowel diseases. Inflamm Bowel Dis 11: 1097-1107, 2005.

6. Asher G, Bercovich Z, Tsvetkov P, Shaul Y and Kahana C: $20 \mathrm{~S}$ proteasomal degradation of ornithine decarboxylase is regulated by NQO1. Mol Cell 17: 645-655, 2005.

7. Strehl B, Seifert U, Krüger E, Heink S, Kuckelkorn U and Kloetzel PM: Interferon- $\gamma$, the functional plasticity of the ubiquitin-proteasome system, and MHC class I antigen processing. Immunol Rev 207: 19-30, 2005.

8. Sakai N, Sawada MT and Sawada H: Non-traditional roles of ubiquitin-proteasome system in fertilization and gametogenesis. Int J Biochem Cell Biol 36: 776-784, 2004.

9. Heinemeyer W, Kleinschmidt JA, Saidowsky J, Escher C and Wolf DH: Proteinase yscE, the yeast proteasome/multicatalyticmultifunctional proteinase: Mutant unravels its function in stress proteolysis and uncovers its necessity for cell survival. EMBO J 10: 555-562, 1991.

10. Shinohara K, Tomioka M, Nakano $\mathrm{H}$, Toné $\mathrm{S}$, Ito $\mathrm{H}$ and Kawashima S: Apoptosis induction resulting from proteasome inhibition. Biochem J 317: 385-388, 1996.

11. Delic J, Masdehors P, Omura S, Cosset JM, Dumont J, Binet J and Magdelenat $\mathrm{H}$ : The proteasome inhibitor lactacystin induces apoptosis and sensitizes chemo- and radioresistant human lymphocytic leukemia lymphocytes to TNF- $\alpha$ initiated apoptosis. Br J Cancer 77: 1103-1107, 1998.

12. Ma MH, Yang HH, Parker K, et al: The proteasome inhibitor PS-341 markedly enhances sensitivity of myeloma tumor cells to chemotherapeutic agents. Clin Cancer Res 9: 1136-1144, 2003.

13. Teicher BA: Newer cytotoxic agents: attacking cancer broadly. Clin Cancer Res 14: 1610-1617, 2008.

14. Rajkumar SV, Richardson PG, Hideshima T and Anderson KC: Proteasome inhibition as a novel therapeutic target in human cancer. J Clin Oncol 23: 630-639, 2005.

15. Obeng EA, Carlson LM, Gutman DM, Harrington WJ Jr, Lee KP and Boise LH: Proteasome inhibitors induce a terminal unfolded protein response in multiple myeloma cells. Blood 107: 4907-4919, 2006.

16. Velazquez OC, Lederer HM and Rombeau JL: Butyrate and the colonocyte: production, absorption, metabolism, and therapeutic implications. Adv Exp Med Biol 427: 123-134, 1997.

17. Macfarlane GT and Gibson GR: Microbiological aspects of the production of short-chain fatty acids in the large bowel. In: Physiological and Clinical Aspects of Short-Chain Fatty Acids. Cambridge University Press, Cambridge, pp87-105, 1995.

18. Pouillart PR: Role of butyric acid and its derivatives in the treatment of colorectal cancer and hemoglobinopathies. Life Sci 63: 1739-1760, 1998. 
19. Kruth J, Defer N and Tichonicky L: Molecular and cellular action of butyrate. C R Seances Soc Biol Fil 186: 12-25, 1992.

20. Velazquez OC and Rombeau JL: Butyrate: potential role in colon cancer prevention and treatment. Adv Exp Med Biol 427: 169-181, 1997.

21. Abaza MSI, Bahman A and Al-Attiyah R: Roscovitine synergizes with conventional chemotherapeutic drugs to induce efficient apoptosis of human colorectal cancer cells. World J Gasteroenterol 14: 5162-5175, 2008.

22. Lam PK, To EW, Chan ES, Liew CT, Lung IW and King WK: In vitro modulation of head and neck cell growth by human recombinant interferon $\alpha$ and 13-cis-retinoic acid. Br J Biomed Sci 58: 226-229, 2001.

23. Abaza MSI, Al-Saffar AM, Al-Sawan SM and Al-Attiyah R: $c$-myc antisense oligonucleotides sensitize human colorectal cancer cells to chemotherapeutic drugs. Tumor Biol 29: 287-303, 2008.

24. Fan XM, Wong BC, Wang WP, et al: Inhibition of proteasome function induced apoptosis in gastric cancer. Int J Cancer 93 481-488, 2001

25. Yang J, Liu X, Bhalla K, Kim CN, Ibrado AM, Cai J, Peng T, Jones DP and Wang X: Prevention of apoptosis by Bcl-2: release of cytochrome $c$ from mitochondria blocked. Science 275 1129-1132, 1997.

26. Wilson MR: Apoptosis: unmasking the executioner. Cell Death Differ 5: 646-652, 1998.

27. Green DR and Reed JC: Mitochondria and apoptosis. Science 281: 1309-1312, 1998.

28. Schendel SL, Montal M and Reed JC: Bcl-2 family proteins as ion-channels. Cell Death Diff 5: 372-380, 1998.

29. Lee S, Christakos S and Small MB: Apoptosis and signal transduction: clues to a molecular mechanisms. Curr Opin Cell Biol 5: 286-289, 1993.

30. Lopes UG, Erhardt P, Yao R and Cooper GM: p53-dependent induction of apoptosis by proteasome inhibitors. J Biol Chem 272: 12893-12896, 1997.

31. Blagosklonny MV, Wu GS, Omura S and El-Deriry WS: Proteasome-dependent regulation of $\mathrm{p} 21^{\text {Waf } 1 / \text { Cipl }}$ expression. Biochem Biophys Res Commun 227: 564-569, 1996.

32. Pagano M, Tam SW, Theodoras AM, Beer-Romero P, Del Sal G, Chau V, Yew PR, et al: Role of the ubiquitin-proteasome pathway in regulating abundance of the cyclin-dependent kinase inhibitor p27. Science 269: 682-685, 1995.

33. Orlowski RZ: The role of the ubiquitin-proteasome pathway in apoptosis. Cell Death Diff 6: 303-313, 1999.

34. Finucane DM, Wetzel-Bossy E, Waterhouse NJ, Cotter TG and Green DR: Bax-induced caspase activation and apoptosis via cytochrome $c$ release from mitochondria is inhibitable by Bcl-XL. J Biol Chem 274: 2225-2233, 1999.

35. Ciechanover A: Proteolysis from the lysosome to ubiquitin and the proteasome. Nat Rev Mol Cell Biol 6: 79-87, 2005.

36. Admas J: The proteasome: a suitable antineoplastic target. Nat Rev Cancer 4: 349-360, 2004.

37. Richardson PG, Sonneveld P, Schuster MW, et al: Bortezomib or high-dose dexamethsome for relapsed multiple myeloma. N Engl J Med 352: 2487-2498, 2005

38. Goy A, Younes A, McLaughlin P, et al: Phase II study of proteasome inhibitor bortezomib in relapsed or refractory B-cell non-Hodgkin's lymphoma. J Clin Oncol 23: 667-675, 2005.

39. Hacihanefioglu A, Tarkun P and Gonullu E: Acute severe cardiac failure in a myeloma patient due to proteasome inhibitor bortezomib. Int J Hematol 88: 219-222, 2008.

40. Enrico O, Gabriele B, Nadia C, et al: Unexpected cardiotoxicity in haematological bortezomib-treated patients. $\mathrm{Br} \mathrm{J}$ Haematol 138: 396-397, 2007.

41. Richardson PG, Briemberg H, Jagannath S, et al: Frequency, characteristics, and reversibility of peripheral neuropathy during treatment of advanced multiple myeloma with bortezomib. J Clin Oncol 24: 3113-3120, 2006.

42. Lonial S, Waller EK, Richardson PG, et al: Risk factors and kinetics of thrombocytopenia associated with bortezomib for relapsed, refractory multiple myeloma. Blood 106: 3777-3784, 2005.

43. Papandreou CN, Daliani DD, Nix D, et al: Phase I trial of the proteasome inhibitor bortezomib in patients with advanced solid tumors with observations in androgen-independent prostate cancer. J Clin Oncol 22: 2108-2121, 2004
44. McConkey D and Zhu K: Mechanisms of proteasome inhibitor action and resistance in cancer. Drug Resist Updates 11: 164-179, 2008.

45. Andrews PA and Howell SB: Cellular pharmacology of cisplatin: perspectives on mechanisms of acquired resistance. Cancer Cell 2: 35-43, 1990

46. Miller AA, Kurschel E, Osieka P and Schmidt CG: Clinical pharmacology of sodium butyrate in patients with acute leukemia. Eur J Cancer Clin Oncol 23: 1283-1287, 1987.

47. Giuliano M, Lauricella M, Calvaruso G, Carabillo M, Emanuele S, Vento R and Tesoriere G: The apoptotic effects and synergistic interaction of sodium butytrate and MG132 in human retinoblastoma Y79 cells. Cancer Res 59: 5586-5595, 1999.

48. Kim OH, Lim JH, Woo KJ, Kim YH, Jin IN, Han ST, Park JW and Kwon TK: Influence of p53 and p21 $1^{\text {waf1 }}$ expression on $\mathrm{G}_{2} / \mathrm{M}$ phase arrest of colorectal carcinoma HCT116 cells to proteasome inhibitors. Int J Oncol 24: 935-941, 2004.

49. Wu WK, Sung JY, Wu YC, Li ZJ, Yu L and Cho CH: Bone morphogenetic protein signaling is required for the anti-mitogenic effect of the proteasome inhibitor MG-132 on colon cancer cells. Br J Pharmacol 154: 632-638, 2008.

50. Denlinger CE, Keller MD, Mayo MW, Broad RM and Jones DR: Combined proteasome and histone deacetylase inhibition in non-small cell lung cancer. J Thorac Cardiovasc Surg 127: 1087-1086, 2004.

51. Abramova M, Pospelova TV, Nikulenkov FP, Hollander CM, Fornace AJ Jr and Pospelov VA: $\mathrm{G}_{1} / \mathrm{S}$ arrest induced by deacetylase inhibitor sodium butyrate in E1A+Ras-transformed cells is mediated through down-regulation of E2F activity and stabilization of $\beta$-catenin. J Biol Chem 281: 21040-21051, 2006.

52. Lauricella M, Calvaruso G, Giuliano M, Carabillo M, Emanuele S and Vento R: Synergistic cytotoxic interactions between butyrate, MG132 and camptothecin in human retinoblastoma Y79 cells. Tumor Biol 21: 337-348, 2000.

53. Kitagawa H, Tani E, Ikemoto H, Ozaki I, Nakano A and Omura S: Proteasome inhibitors induce mitochondria-independent apoptosis in human glioma cells. FEBS Lett 443: 181-186, 1999.

54. Katayose Y, Kim M, Rakkar ANS, Li Z, Cowan KH and Seth P: Promoting apoptosis: a novel activity associated with the cyclindependent kinase inhibitor p27. Cancer Res 57: 5441-5446, 1997.

55. Timmerbeul I, Garrett-Engele CM, Kossatz U, et al: Testing the importance of p27 degradation by the SCFskp2 pathway in murine models of lung and colon cancer. Proc Natl Acad Sci USA 103: 14009-14014, 2006.

56. Pandit B and Gartel AL: New potential anti-cancer agents synergize with bortezomib and ABT-737 against prostate cancer. Prostate 70: 825-833, 2010.

57. Chauhan D, Singh AV, Ciccarelli B, Richardson PG, Palladino MA and Anderson KC: Combination of novel proteasome inhibitor NPI-5552 and lenalidomide trigger in vitro and in vivo synergistic cytotoxicity in multiple myeloma. Blood 115: 834-845, 2009

58. Matondo M, Bousquet-Dubouch MP, Gallay N, et al: Proteasome inhibitor-induced apoptosis in acute myeloid leukemia: A correlation with proteasome status. Leuk Res 34: 498-506, 2009.

59. Yuan JY, Shaham S, Ledoux S, Ellis HM and Horvitz HR: The C. elegans cell death gene ced-3 encodes a protein similar to mammalian interleukin-1 beta-converting enzyme. Cell 75: 641-652, 1993.

60. Nicholson DW and Thornberry NA: Caspases: killer proteases. Trends Biochem Sci 22: 299-306, 1997.

61. Talanian RV, Quinlan C, Trautz S, et al: Substrate specificities of caspase family proteases. J Biol Chem 272: 9677-9682, 1997.

62. Fuchs $\mathrm{E}$ and Weber K: Intermediate filaments: structure, dynamics, function, and disease. Ann Rev Biochem 63: 345-382, 1994.

63. Germain M, Affar EB, D'Amours D, Dixit VM, Salvesen GS and Poirier GG: Cleavage of auto-modified poly(ADP-ribose)polymerase during apoptosis. Evidence for involvement of caspase-7. J Biol Chem 274: 28379-28384, 1999.

64. Cuvillier O, Rosenthal DS, Smulson ME and Spiegel S: Shingosine-1-phosphate inhibits activation of caspases that cleave poly(ADP-ribose) polymerase and lamins during Fas- and ceramide-mediated apoptosis in Jurkat lymphocytes. J Biol Chem 273: 29010-29016, 1998.

65. Reed JC: Bcl-2 and the regulation of programmed cell death. J Cell Biol 124: 1-6, 1994. 
66. Liu X, Kim CN, Yang J, Jemmerson R and Wang X: Induction of apoptotic program in cell-free extracts: requirement for dATP and cytochrome $c$. Cell 96: 147-157, 1999.

67. Chandra J, Niemer I, Gilbreath J, et al: Proteasome inhibitors induce apoptosis in glucocorticoid-resistant chronic lymphocytic leukemic lymphocytes. Blood 92: 4220-4229, 1998.

68. Chen YR, Wang X, Templeton D, Davis RJ and Tan TH: The role of c-jun N-terminal kinase (JNK) in apoptosis induced by ultraviolet C and $\lambda$ radiation. J Biol Chem 31929-31936, 1996.

69. Williams SA and McConkey DJ: The proteasome inhibitor bortezomib stabilizes a novel active form of p53 in human LNCaP-Pro5 prostate cancer cells. Cancer Res 63: 7338-7344, 2003.

70. Medina V, Edmonds B, Young GP, James R, Appleton S and Zalewski PD: Induction of caspase-3 protease activity and apoptosis by butyrate and trichostatin-A (inhibitors of histone deacetylase): dependence on protein synthesis and synergy with a mitochondrial/cytochrome $c$-dependent pathway. Cancer Res 57: 3697-3707, 1997.
71. Lara PN, Davies AM, Mack PC, Mortenson MM, Bold RJ, Gumerlock PH and Gandara DR: Proteasome inhibition with PS-341 (bortezomib) in lung cancer therapy. Sem Oncol 31: 40-46, 2004.

72. Zhu H, Zhang L, Dong F, et al: Bik/NBK accumulation correlates with apoptosis-induction by bortezomib (PS-341, Velcade) and other proteasome inhibitors. Oncogene 24: 4993-4999, 2005.

73. Goldstein JC, Waterhouse NJ, Juin P, Evan GI and Green DR: The coordinate release of cytochrome c during apoptosis is rapid, complete and kinetically invariant. Nat Cell Biol 2: 156-162, 2000.

74. Daly K and Shirazi-Beechey SP: Microarray analysis of butyrate-regulated genes in colonic epithelial cells. DNA Cell Biol 25: 49-62, 2006.

75. Davie JR: Inhibition of histone deacetylase activity by butyrate. J Nutr 133 (Suppl 7): 2485s-2493s, 2003. 